\title{
Review \\ Role of Quercetin in Depressive-Like Behaviors: Findings from Animal Models
}

\author{
Serena Silvestro (D), Placido Bramanti and Emanuela Mazzon *
}

Citation: Silvestro, S.; Bramanti, P.;

Mazzon, E. Role of Quercetin in

Depressive-Like Behaviors: Findings from Animal Models. Appl. Sci. 2021, 11, 7116. https://doi.org/ 10.3390/app11157116

Academic Editors: Gang Ma, Masaya Kato and Pongphen Jitareerat

Received: 30 June 2021

Accepted: 30 July 2021

Published: 31 July 2021

Publisher's Note: MDPI stays neutral with regard to jurisdictional claims in published maps and institutional affiliations.

Copyright: (C) 2021 by the authors Licensee MDPI, Basel, Switzerland. This article is an open access article distributed under the terms and conditions of the Creative Commons Attribution (CC BY) license (https:// creativecommons.org/licenses/by/ $4.0 /)$.
IRCCS Centro Neurolesi “Bonino-Pulejo”, Via Provinciale Palermo, Contrada Casazza, 98124 Messina, Italy; serena.silvestro@irccsme.it (S.S.); placido.bramanti@irccsme.it (P.B.)

* Correspondence: emanuela.mazzon@irccsme.it; Tel.: +39-090-60128172

\begin{abstract}
Depressive-like behavior is a highly prevalent worldwide neuropsychiatric disorder that owns a complex pathophysiologic mechanism. The available pharmacotherapy is ineffective for most patients and shown several adverse effects. Therefore, it is important to find efficacy and safe antidepressive compounds. Some phytochemicals compounds regulate the same genes and pathways targeted by drugs; therefore, diets rich in fruits and vegetables could be considered novel treatment approaches. Currently, the functional properties of quercetin acquired great interest, due to its beneficial effects on health. Quercetin is a flavonoid ubiquitously present in vegetables and fruits, interestingly for its strong antioxidant properties. The purpose of this review is to summarize the preclinical studies present in the literature, in the last ten years, aimed at illustrating the effects of quercetin pre-treatment in depressive-like behaviors. Quercetin resulted in antidepressant-like actions due to its antioxidant, anti-inflammatory, and neuroprotective effects. This pointed out the usefulness of this flavonoid as a nutraceutical compound against the development of psychological stress-induced behavioral perturbation. Therefore, quercetin or a diet containing it may become a prospective supplementation or an efficient adjuvant therapy for preventing stress-mediated depressive-like behavior.
\end{abstract}

Keywords: quercetin; depressive-like behaviors; antioxidant; anti-inflammatory; neuroprotection; antidepressive

\section{Introduction}

Depressive-like behaviors are a mental disorder that affects approximately 264 million people around the world. Depression is often characterized by cognitive impairment and anxiety [1,2]. Furthermore, this condition is known to impair the functions of the hippocampus and the prefrontal cortex [3]. Both brain structures play an important role in decision-making processes, therefore dysfunction at this level can induce a greater predisposition to negative emotions [4]. In these areas are located many glucocorticoid receptors involved in depressive-like behaviors [5]. Noteworthy, the glucocorticoid receptors mediate the regulation of the hypothalamic-pituitary-adrenal (HPA) axis through negative feedback inhibitory mechanisms. The HPA axis promotes the secretion of corticotropin-releasing hormone that is transported in the anterior pituitary and induces the release of adrenocorticotropic hormone, which in turn stimulates the adrenal cortex to secrete glucocorticoids such as cortisol which binds to receptors intracellular for glucocorticoids [6]. Moreover, the HPA axis plays an important role in the response to external stimuli and internal, such as psychological stresses [7]. Indeed, it was observed that chronic stress induces depression [8], highlighting the close relationship between oxidative stress and mood disturbance [9]. This condition is characterized by a complex pathophysiological mechanism, that also involves the reduction of the monoamine system such as neurotransmission of serotonin, dopamine, and noradrenaline [10]. Additionally, immunological alterations and excessive inflammation are further pathological events that play an important role in depression [11,12]. 
Most antidepressant drugs aim at correcting the neurotransmitter imbalances involved in the regulation of the mind and emotions [13]. However, there is a high rate of treatmentresistant depressed subjects. Additionally, most anti-depressants own a long latency and numerous side effects. Therefore, the need for new, more efficient and safe antidepressant drugs is growing. Today, phytotherapy, which promotes the application of plants in the treatment of diseases [14], represents a useful source for the development of more effective antidepressants. Several medicinal plants were used in the treatment of various neurological diseases [15,16]. Phenolic compounds such as flavonoids represent a promising class of natural compounds important in neuropharmacology, thanks to their antioxidant and neuroprotective properties [17]. Fruits and vegetables, important sources in the daily diet, are reservoirs of these bioactive compounds [18].

Flavonoids are a class of polyphenols, widely distributed in the plant kingdom, thus, with a normal diet, humans take an average of 1-2 g/day [19]. Among them, quercetin $\left(3,3^{\prime}, 4^{\prime}, 5,7\right.$-pentahydroxyflavone) is the flavonoid most abundant in food and consumed by humans [20]. Several evidences show that fruit and vegetable thanks to their high content of quercetin protect brain tissue from neurodegeneration induced by oxidative stress [21,22]. Quercetin protects neurons from oxidative stress by inhibiting the formation of hydroperoxide, reducing free radicals and restoring antioxidant enzymes [23,24]. Additionally, quercetin due to its ability to cross the blood-brain barrier appears in the brain several hours after administration, thus, exerting its neuroprotective effects [25]. It has also been shown to exert anxiolytic effects and improve cognitive deficits [26]. Several findings highlight the protective role of quercetin against depressive-like disorders. Indeed, the freeze-dried onion powder and Ginkgo biloba leaves, rich in quercetin, have an antidepressant action $[27,28]$. Moreover, this flavonoid improving behavioral disturbances in mice and rats with anxiety and depressive-like behaviors induced by the corticotropin-releasing factor $[29,30]$.

In this regard, the purpose of this review was to provide an overview of quercetin's potentials properties in depressive-like behaviors. In the present paper, preclinical evidence highlighting the antioxidants, anti-inflammatory and neuroprotective effects of quercetin in this disorder was summarized.

\section{Methodology}

The aim of this review was to provide an overview of experimental studies that report quercetin's functional properties in depressive-like behaviors. In order to write the paragraph " 5 . Quercetin and depressive-like behaviors", the bibliography research in PubMed was performed using the following keywords: "quercetin" and "depression like behaviors". We considered articles published between 2011 and 2021 demonstrating an antidepressive role of quercetin. In this search, 33 articles were found, as shown in the Prisma flow diagram (Figure 1). In the "Records screened" section, 4 articles were excluded; 3 were not considered because they were different from the focus of our review. 1 other article was excluded because there is a corrigendum in the article. In the "Full-text articles assessed for eligibility" section, 11 articles were excluded; 10 were not described because they focused on the antidepressive role of other compounds. As this review is intended to provide an overview of experimental studies, 1 other article was excluded because it is a review. Finally, in this manuscript there were 18 studies considered that evaluate the biochemical and molecular mechanisms underlying the antidepressive effects of quercetin in depressive-like behaviors. 

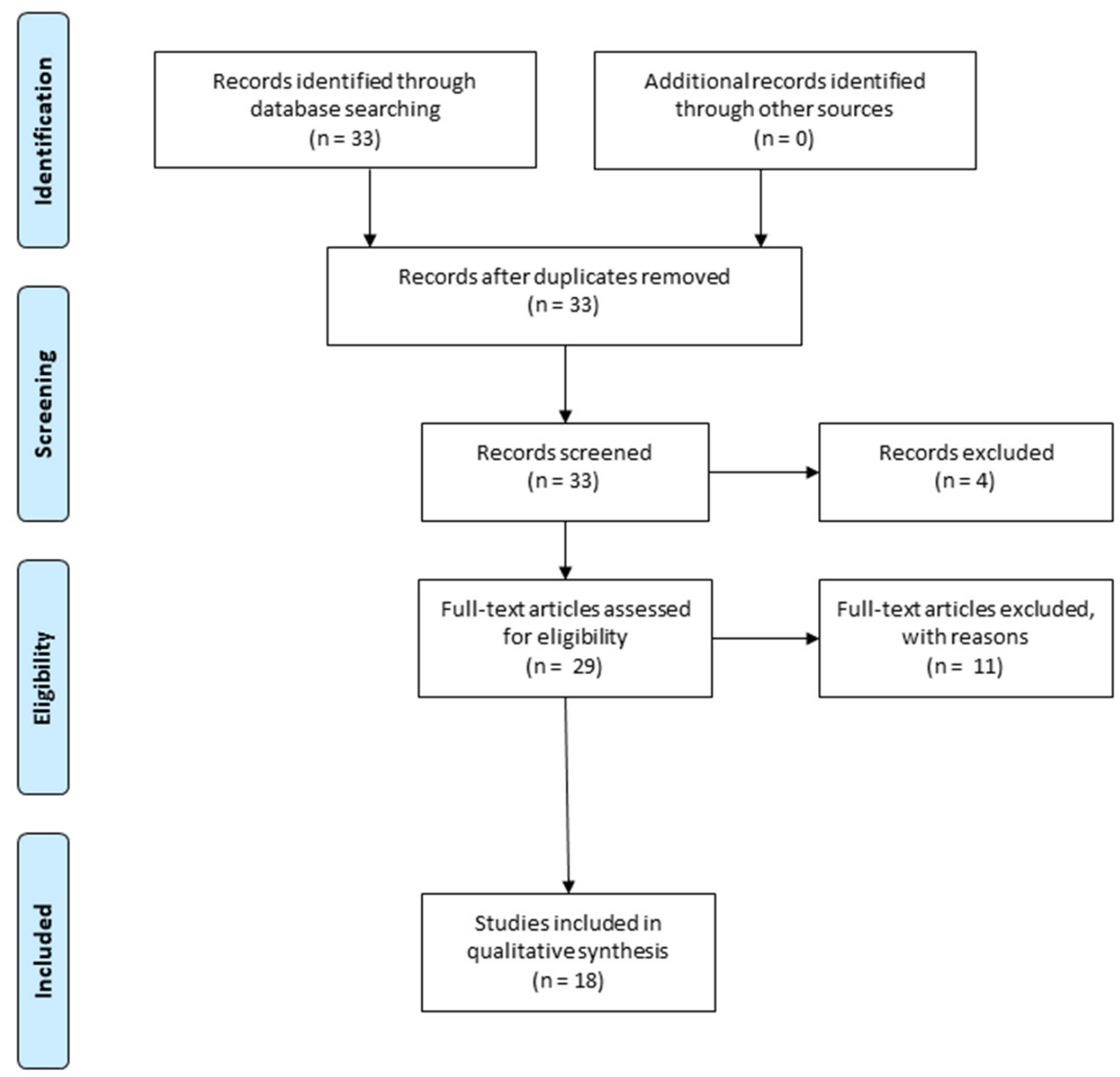

Figure 1. Prisma flow diagram illustrating the selection methodology of the preclinical studies used for the writing of the review. There were experimental studies considered that evaluate quercetin's functional properties in depressive-like behaviors, highlighting biochemical and molecular mechanisms underlying its beneficial effects (The PRISMA Statement was published in: [31]).

Animal studies described were performed as set out by the National Institutes of Health Guidelines on the use of laboratory animals. Moreover, research conducted in experimental animals needs approval by a properly constituted research ethics committee. All experiments mentioned in the manuscript were approved by the ethics committee, reported in Table 1. 
Table 1. Details of the approval by the appropriately constituted research ethics committee (project identification code, date of approval, and name of the ethics committee or institutional review committee) of studies performed on the animal models mentioned in the manuscript.

\begin{tabular}{|c|c|c|c|c|}
\hline Authors Names & $\begin{array}{l}\text { Name of the Ethics Committee or } \\
\text { Institutional Review Board }\end{array}$ & $\begin{array}{l}\text { Project Identification } \\
\text { Code }\end{array}$ & Date of Approval & Reference \\
\hline Samad $\mathrm{N}$ et al. & $\begin{array}{l}\text { Institutional ethics and animal care } \\
\text { committee }\end{array}$ & - & - & [32] \\
\hline Singh V. et al. & $\begin{array}{l}\text { Institutional Animal Ethics } \\
\text { Committee (IAEC) }\end{array}$ & $\begin{array}{c}\text { No. } \\
\text { 107/GO/ReBi/S/99 } \\
\text { /CPCSEA/2017-01 }\end{array}$ & 27 February 2017 & [33] \\
\hline Khan K. et al. & $\begin{array}{l}\text { Institutional Animal Ethics } \\
\text { Committee (IAEC) }\end{array}$ & No. 1314. & - & {$[34]$} \\
\hline Mehta V. et al. & $\begin{array}{l}\text { Institute Animal Ethics Committee in } \\
\text { accordance with the guidelines of } \\
\text { CPCSEA, India }\end{array}$ & - & - & [35] \\
\hline Shen, Z. et al. & $\begin{array}{l}\text { Institutional Animal Care and Use } \\
\text { Committee at Jiaxing University }\end{array}$ & - & - & [36] \\
\hline Ma Z.X. et al. & $\begin{array}{c}\text { General Project of Science and } \\
\text { Technology Development Fund of } \\
\text { Nanjing Medical University (Item) }\end{array}$ & No. NMUB2019114 & - & [37] \\
\hline Donoso F. et al. & $\begin{array}{l}\text { Ethics Committee of University } \\
\text { College Cork }\end{array}$ & - & - & [38] \\
\hline Sahin T.D. et al. & $\begin{array}{l}\text { Animal Research Ethics Committee of } \\
\text { Kocaeli University, Turkey }\end{array}$ & $\begin{array}{l}\text { No: KOÜ HADYEK } \\
\text { 2/9-2017 }\end{array}$ & $09 / 02 / 2017$ & [39] \\
\hline Anggreini P. et al. & $\begin{array}{c}\text { Ethical Committee of the Faculty of } \\
\text { Veterinary Medicine, } \\
\text { Universitas Airlangga }\end{array}$ & No. 2.KE.007.05.2019. & - & [40] \\
\hline Zhang J. et al. & $\begin{array}{l}\text { Institutional Animal Care and Use } \\
\text { Committee (IACUC) of University of } \\
\text { Science and Technology of China. }\end{array}$ & - & - & [41] \\
\hline Guan et al. & $\begin{array}{l}\text { Medical Ethics Committee of Harbin } \\
\text { Medical University }\end{array}$ & - & - & [42] \\
\hline Fang K. et al. & $\begin{array}{c}\text { Animal Care and Use committee at } \\
\text { Anhui Medical University }\end{array}$ & - & - & [43] \\
\hline Sadighparvar S. et al. & $\begin{array}{c}\text { Animal Care and Use Committee at the } \\
\text { Urmia University of Medical Sciences, } \\
\text { Urmia, Iran }\end{array}$ & IR.UMSU.REC.1396.316 & - & [44] \\
\hline Wang G. et al. & $\begin{array}{l}\text { Animal Care Committee of } \\
\text { Jinan University }\end{array}$ & No. $2,019,671$ & - & [45] \\
\hline Merzoug S et al. & $\begin{array}{l}\text { NIH revised Guidelines for the Care } \\
\text { and Use of Laboratory Animals }\end{array}$ & No. $80-23$ & - & [46] \\
\hline Demir E.A. et al. & $\begin{array}{l}\text { Local Ethics and Animal Care } \\
\text { Committee of Necmettin } \\
\text { Erbakan University }\end{array}$ & 2013-053 & - & [47] \\
\hline Holzmann et al. & $\begin{array}{l}\text { Institutional Ethics Committee of } \\
\text { UNIVALI, Itajaí, SC, Brazil }\end{array}$ & No.021/13 & - & [48] \\
\hline Rinwa P. et al. & $\begin{array}{l}\text { Institutional Animal Ethics Committee } \\
\text { (IAEC) of the Panjab University }\end{array}$ & IAEC/282/UIPS/39 & $30 / 8 / 12$ & [49] \\
\hline
\end{tabular}




\section{Quercetin}

Fruits and vegetables thanks to their flavonoid content, acquired considerable scientific interest. The flavonoid content in fruit and vegetables is influenced by several pre-harvest factors, such as crop variations, climatic conditions, growing locations, agronomic factors, and harvest factors, such as maturity stage [50-52]. It has shown that in onions, rich in flavonols (quercetin), the content of these compounds vary according to the cultivation as well as within its layers. Indeed, it has reported that the onion's dry peel shows a total phenols content 100 times higher than the bulbs and stems [50]. Environmental factors such as solar radiation, temperature variation and climatic conditions modify the flavonoid content in fruits and vegetables. Indeed, some researchers observed that solar radiation during the growing period significantly increases the quercetin content (from 1.43 to $8.1 \mathrm{mg} / 100 \mathrm{~g}$ fresh weight) [53]. Furthermore, solar radiation in the onion bulb increased the quercetin concentration from 10 to $50 \mathrm{mg} / 100 \mathrm{~g}$ fresh weight during the last growth phase [54]. Furthermore, the location and soil type represent important factors that change quercetin concentrations [55]. The ripeness stage can also influence the level of phytocompounds. In onions, an early lifting time results in low germination and a reduced level of quercetin [54]. However, in addition to these pre-harvest factors, several post-harvest phases affect the content of these phytocompounds within fruits and vegetables. Conventional transformation processes such as high-pressure pulsed electric field, ultrasound/sonication, ozone, ultraviolet, and processes such as washing, peeling, cutting, canning, and drying are known to degrade flavonoid content [56-58]. Microwaving in the onions induces a 16-18\% reduction in the glycoside content of quercetin [59]. Peeling in the onions also caused a reduction in 79\% quercetin glycosides [60]. Similarly, a 60-min boil causes a reduction of about 44-53\% [59]. Therefore, the development of new preand post-technology collections, could be important to improve the accumulation of phytocompounds in fruit and vegetables.

Flavonoids belong to the large family of low molecular weight phenols which, based on their molecular structures, are divided into flavones, flavanones, isoflavones, isoflavans, pterocarpans, coumestans, anthocyanins, flavanols (or catechins), and flavonols [61,62]. Among these flavonols such as kaempeferol, quercetin and myricetin, are the most represented flavonoids thanks to their functional properties [63].

Fruits and vegetables (e.g., onions, apples, tea and berries, peppers cranberries, apples, cherries, and grapes) contain a high content of quercetin in the glycone or carbohydrate conjugates form. Indeed, the major quercetin-dietary intake consists of quercetin glycosides, a molecular of quercetin conjugates with one or two glucose residues or with routine. Interestingly, the growing conditions influence the amount of quercetin in food, indeed, compared to organically grown, conventionally cultivated tomatoes contained a lower amount of quercetin aglycone [64]. Quercetin is an abundantly represented source in the daily diet. It has been estimated that the daily intake of quercetin is around $5-40 \mathrm{mg}$. Instead, when quercetin took as a food supplement, the recommended do e is 200-1200 mg [65]. Quercetin belongs to the flavonols family and owns 3-hydroxyflavone backbone (Figure 2). 


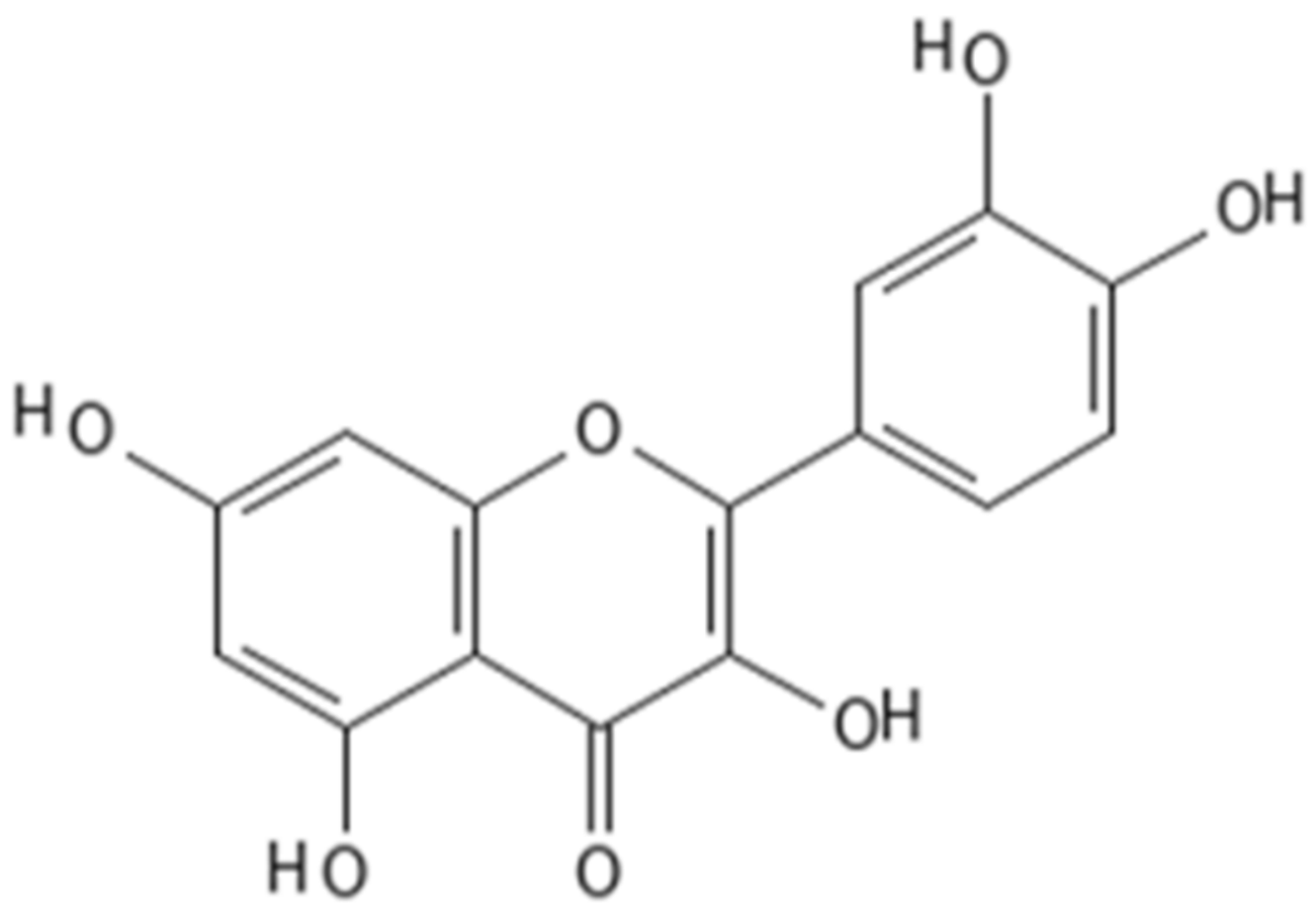

Figure 2. The chemical structure of quercetin. The image of quercetin was created using PubChem Sketcher V2.4 (https: / / pubchem.ncbi.nlm.nih.gov/edit3/index.html/, accessed on 21 June 2021).

Quercetin is a powerful antioxidant, due to the catechol group and the hydroxyl group present in the molecular structure which confers it's an optimal conformation useful as a scavenger of free radicals [66]. Indeed, this flavonoid is a powerful inhibitor of lipid peroxidation, by reducing both cyclooxygenase and lipoxygenase activity. This is responsible for reducing the formation of inflammatory metabolites [67-69]. Furthermore, quercetin is also responsible for increasing antioxidant enzymes, preventing the formation of free radicals [70]. It also has the ability to chelate transition metal ions [71,72]. Due to its iron-chelating and iron-stabilizing properties, it thus removes the potential factors of reactive oxygen species (ROS) formation [73].

\section{Depressive-Like Behaviors}

Depression is a mood disorder triggered by multiple causes: hereditary factors, social environment, family mourning, work problems, etc. [74]. Several evidence showed that depression should be considered a systemic disease as it causes major alterations in oxidative stress with repercussions on the entire body [75].

The World Health Organization considers depression, the second cause of disability, second only to infarction. About 340 million people suffer from depression and the most affected age range is between 30 and 49 years, most often among women [76]. Unlike neurodegenerative diseases that are characterized by lesions in specific regions of the central nervous system, depression involves a very wide neural circuit and many regions such as cortical districts (regions of the prefrontal cortex and hippocampus); and subcortical districts (hypothalamus) [3]. There are many types of depression and depending on the type, the severity of the symptoms and the age of onset can be classified as such: disruptive mood dysregulation disorder; major depressive disorder; persistent depressive disorder (dysthymia); and premenstrual dysphoric disorder [77].

Although the causes of depression can be multiple, the psychological factor such as experiences, emotions. and strongly negative feelings experienced in the duration of your life can make you vulnerable to depression. Moreover, there is a greater genetic predisposition, as well as some inheritance, towards depression [78]. There seems to be 
a relationship between specific genes and the vulnerability to depression. Indeed, it was observed that people with altered levels of neuronal transporter gene SLC6A15 in specific brain regions involved in emotional regulation are more vulnerable to depression or other stress-related emotional issues [79].

Typical symptoms of depression are fatigue, difficulty in concentration and memory, loss of energy, nervousness, sleep disturbances (insomnia or hypersomnia), loss or weight gain, and lack of sexual desire [80]. Cognitive symptoms are mental enumeration, difficulty in making decisions and solving problems, catastrophic thought and pessimistic thought, self-criticism, and self-assessment. Many of these symptoms are to be attributed to the association between monoamine neurotransmitters (serotonin, noradrenaline, and dopamine) and depression. In depressed patients, there is a synaptic alteration that involves synergistically neurotransmitters: dopamine-noradrenaline-serotonin [81]. Thus, a decrease in noradrenaline may be associated with loss of alertness, attention, energy, and interest in life. A reduction in serotonin induces anxiety, obsessions, and compulsions; contrarily, a decrease in dopamine from the prefrontal cortex to loss of motivation and pleasure [82]. Indeed, increased dopamine transporter levels and decreased dopamine levels were observed in patients with the major depressive disorder [83,84].

Depression has also related to immune mechanisms and the biological molecules involved in these processes termed cytokines (Figure 3) [11]. Indeed, depressed subjects show high levels of pro-inflammatory cytokines such as interleukin (IL)-1, IL-2, IL-6, and tumor necrosis factor-alpha (TNF- $\alpha$ ) $[85,86]$. The activation of the inflammatory immune system inhibits neurogenesis, resulting in a reduction in the prefrontal cortex and hippocampus in depressed subjects [87]. Moreover, cytokines, are also humoral mediators of innate and adaptive immunity and are also important mood modulators. Indeed, proinflammatory cytokines exalt the HPA axis, inducing a powerful increase of glucocorticoids into the bloodstream [88]. Especially, severe forms of depression are characterized by a constant over-activity of the HPA axis and a dysregulation of the autonomic nervous system [89]. Specifically, the activation of HPA stimulating the hypothalamic secretion of the corticotropic release hormone and stimulation of the adrenal medulla to produce catecholamines with consequent release of cortisol and ROS [86]. This highlights the relationship between oxidative stress and depressive-like behaviors [90]. Another important mediator involved in the physiopathology of depressive disorder is glutamate. This excitatory neurotransmitter is involved in the function of memory, cognition, learning, and training processes of neural networks. Elevated levels of glutamate inducing excessive stimulation of N-methyl-D-aspartate (NMDA) receptors, responsible for an increased influx of calcium and nitric oxide (NO) [91].

Moreover, it was observed relationships had been noted between depression and the anterior cingulate cortex in the modulation of emotional behavior [92]. The principal neurotrophin that is responsible for neurogenesis is the brain-derived neutrophic factor (BDNF). It was demonstrated that the level of BDNF in the serum of depressed subjects was reduced. Conversely, antidepressant treatment increased the blood level of BDNF. Although decreased serum BDNF is found in other mental disorders, there is notable interest in its links to depression and the action of antidepressants [93]. It is known that impairment of BDNF as well as compromising Transforming-Growth-Factor- $\beta 1$ (TGF$\beta 1)$ signaling and aberrant TNF- $\alpha$ signaling are common pathophysiological events that have been identified in depression and Alzheimer's disease. Indeed, several pieces of evidence highlighted the link between depression and Alzheimer's disease [94]. TGF- $\beta 1$ is an anti-inflammatory cytokine that promotes protection against neurodegeneration induced by amyloid- $\beta$, and it has a key role in memory formation and synaptic plasticity. Interestingly, TGF- $\beta 1$ plasma levels are reduced in major depressed patients and this is related to depression severity. Moreover, TGF- $\beta$, regulating Th1 and Th2 cytokines, could induce beneficial for later response to antidepressive treatment $[95,96]$. 


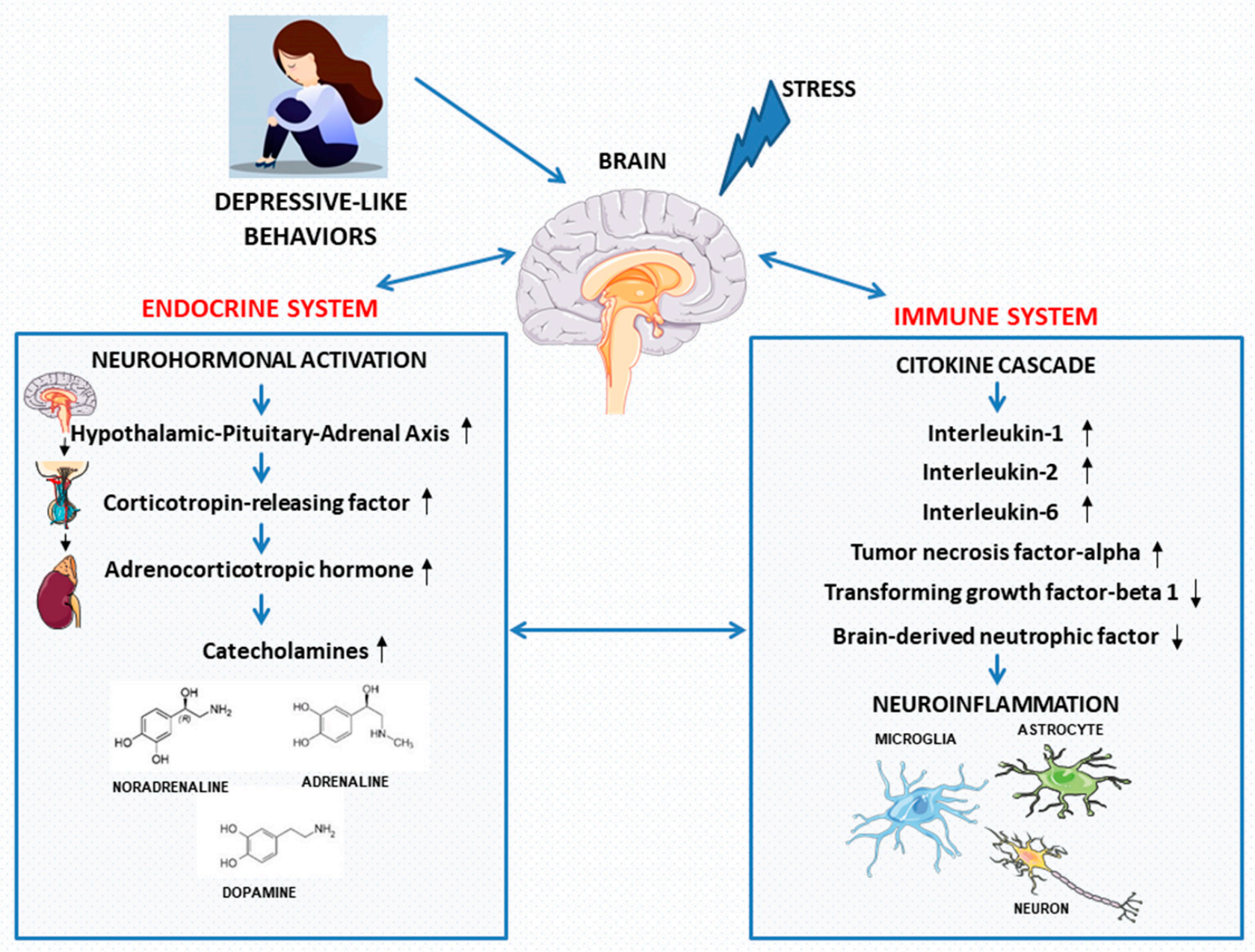

Figure 3. Immune mechanisms and biological molecules involved in the depressive-like behaviors. The figure was drawn using the vector image bank of Servier Medical Art by Servier (available at http:/ / smart.servier.com/, accessed on 21 June 2021). Licensed under a Creative Commons Attribution 3.0 Unported License (https:/ / creativecommons.org/licenses/by/ $3.0 /$, accessed on 21 June 2021).

Treatment of depression is often multimodal and includes both pharmacological and non-pharmacological interventions. The classes of antidepressants including monoamine oxidase (MAO) inhibitors, irreversible inhibitors of MAO enzymes responsible for monoamine metabolism [97]. The selective serotonin reuptake inhibitors (SSRI) block muscarinic, adrenergic, and serotoninergic receptors, selectively bind to serotonin transporter (SERT or 5-HTT), thus inhibiting serotonin reuptake and increasing serotonergic transmission [98]. Tricyclic Antidepressants (TCA) are another class of antidepressants that bind to receptors for the reuptake of both serotonin and noradrenaline, inhibiting them [99]. Selective Noradrenaline Reuptake Inhibitors (NARI) inhibit the norepinephrine reuptake and act selectively to bind the norepinephrine carrier, thus promoting a longer stay of the neurotransmitter in the synaptic spine. The serotoninergic and Noradrenergic Specific Antidepressants (NASSA) acting indirectly on the receptors for the reuptake of noradrenaline and serotonin, they act as antagonists of $\alpha 2$ adrenergic receptors and 5-hydroxytryptamine (5-HT) serotonin receptors [100]. Instead, serotonin reuptake inhibitors and norepinephrine (SNRI) inhibitors, bind to SERT and norepinephrine transporter (NET) receptors inhibiting their reuptake [101]. Finally, the dopamine and norepinephrine reuptake inhibitors (DNRI), are antidepressants class that selectively inhibits the reuptake of dopamine and noradrenaline [102]. 
However, most antidepressant drugs own several side effects, including weight gain, migraines, and sexual disorders [103]. Therefore, the natural compounds contained in fruits and vegetables, arouse the interest of researchers due to their functional properties, their rapid onset of action, and their low ability to induce adverse events.

\section{Quercetin in Animal Models of Depressive-Like Behaviors}

Animal models of depressive-like behavior are important to elucidate the pathophysiology of this disorder and evaluate the mechanism of action of antidepressant compounds $[104,105]$. It appears difficult to create an animal model that perfectly mimics the symptoms of depression in humans, although efforts have been made to establish several animal models [106]. Animal models based on surgery, such as olfactory bulbectomy [107], or acute models, such as tail suspension or forced swimming were the most widely used animal models [108,109]. The bulbectomized rat showed an agitated, hyposerotonergic depression-related phenotype [110]. However, these models are invasive and ineffective. Pharmacological models are used to evaluate responsiveness to antidepressants and characteristic symptoms of depression. The common compounds used are Reserpine, which induces locomotor hypomotility and decreases body temperature in animals, or the Tryptophan, able to enhance the synaptic concentration of serotonin increasing the behavioral syndrome [111]. The psychostimulant withdrawal paradigm is another pharmacological approach used, that induces behavioral changes similar to some aspects of depression in humans [112]. Instead, the genetic approach, using genetically engineered mice are useful for identifying the genetic cause of depressive-like behavior and to create models that meet clinical expectations [113]. Another strategy in genetics is selective breeding, which takes advantage of differences in the individual responsiveness to depression [114]. However, exposure to stress or to traumatic life events represents valid strategies able to reproduce behavioral changes similar to depressive-like behaviors [115]. Consequently, the majority of animal models used to reproduce depressive-like behaviors are based on exposure to various types of acute or chronic stressors that, also, are less invasive, more effective and reliable [116-118]. Exposure of animals to chronic stress induces mood changes, impaired memory and cognitive function [119]. Unpredictable stress is responsible for the increase in the activity of the serotonergic and noradrenergic systems [120]. Stress induces a decrease in neurogenesis in the hippocampus [121], brain damage in the limbic regions and in the cortex [122], alteration of the HPA [123], activation of the inflammatory cytokine cascade and consequent activation of the microglia [124,125].

In order to assess depressive-like behavior in animal models, the most widely used paradigm is the forced swim test (FST). FST is a behavioral test used for the measurement of the efficacy of antidepressant drugs and of new compounds, as well as represents an experimental manipulation in order to induce or prevent depressive-like states and assesses learned helplessness, a feature of depressive-like behavior in rodents [126].

\subsection{Quercetin Effects in Animal Models Exposed to Chronic Stress}

Several evidence showed that quercetin improves stress and depressive-like symptoms enhancing antioxidant enzymes $[127,128]$. Quercetin, due to its ability to cross the blood-brain barrier, appears in the brain after several hours of administration, playing an important role in the central nervous system and induces neuronal survival [25]. It is known to improve stress-induced behavioral dysfunction decreasing oxidative stress in the hippocampus $[29,35]$. Additionally, quercetin ameliorated serotonergic and cholinergic functions following repeated treatment [129]. In this regard, Samad N. et al. evaluated the effects of repeated administration of quercetin on cognitive function, stress responses, cholinergic function, and serotonin metabolism in animals following $2 \mathrm{~h}$ of immobilization stress. Immobilization stress was performed by pressing the forelegs of the rats through the gaps in the metal grids and taping them together with zinc oxide plaster tape, in order to mimics potent physical and psychological stress. Results showed that quercetin treatment $(20 \mathrm{mg} / \mathrm{mL} / \mathrm{kg})$, for 14 days, ameliorated stress-induced anxiety and depres- 
sion. Quercetin reduced the stress-induced lipid peroxidation and increased antioxidant enzymes such as superoxide dismutase (SOD), catalase (CAT), and glutathione peroxidase (GPx). Moreover, quercetin significantly increased acetylcholine (Ach) levels in the brain of stressed than unstressed mice. After $2 \mathrm{~h}$ the immobilization stress increased 5-HT and 5-hydroxyindoleacetic acid (5-HIAA) levels in untreated and treated stressed mice. However, quercetin pre-treatment reduced 5-HIAA levels, showing how quercetin may ameliorate 5-HT function abnormalities under stress. In conclusion, pre-treatment with quercetin mitigated stress-induced behavioral deficits at least in a part due to its antioxidant functional properties. Also, this compound, induced antidepressant and anxiolytic properties, reducing the activity of the serotonergic and cholinergic systems [32].

Singh V. et al., evaluated the effects of quercetin (10 or $20 \mathrm{mg} / \mathrm{kg}$ ) and quercetin $4^{\prime}$-O-glucoside (10 or $20 \mathrm{mg} / \mathrm{kg}$ ) isolated from Allium cepa in a mouse model of unpredictable mild chronic stress-induced depressive behavior. In order to induce the depression model, mice were subjected to several stress regimes of different duration and severity in an unpredictable manner for 3 weeks. After $24 \mathrm{~h}$ of the last stressor, both compounds demonstrated a decrease in immobility time in the FST and an enhancement of the locomotor activity in the open field test compared to the control group. These findings highlighted the antidepressant effect of these compounds. However, quercetin 4'-O-glucoside showed comparable antidepressant action to the fluoxetine $(20 \mathrm{mg} / \mathrm{kg})$ treated group. For this reason, the action of quercetin $4^{\prime}$-O-glucoside $(10$ and $20 \mathrm{mg} / \mathrm{kg})$ was further investigated in a depressive-type mouse model induced by unpredictable mild chronic stress. For 2 weeks, the animals were subjected to various stresses once a day $30 \mathrm{~min}$ after administering the treatments. Quercetin 4'-O-glucoside at both doses restored ROS levels such as thiobarbituric acid reactive species (TBARS) and GSH, reduced monoamine oxidase-A (MAO-A) activity, and increased 5-HT levels in the brain. Therefore, the antidepressant action of quercetin and its glucoside may be linked to their antioxidant action, ability to inhibit MAO-A and restore 5-HT levels [33]. In the same animal model of depression, Khan K. et al. showed that quercetin administered for 28 days, 2 weeks after the onset of stress, induced antidepressant effects such as fluoxetine. Indeed, quercetin $(25 \mathrm{mg} / \mathrm{kg})$, albeit to a lesser extent than fluoxetine $(10 \mathrm{mg} / \mathrm{kg})$, improved the locomotor activity of animals subjected to unpredictable mild chronic stress. In line with the previous study, the antidepressant action of quercetin can be linked to its ability to significantly increase the levels of antioxidants such as SOD, GSH, and CAT and restore the levels of 5-HT in the brain tissue of mice. Additionally, the researchers also showed that quercetin significantly decreased IL- 6 and TNF- $\alpha$ levels in brain tissues, which were increased following model induction. Since an excessive inflammatory response is also often responsible for the increased release of glutamate; quercetin also reduced this excitatory synaptic neurotransmitter. Thus, in addition to antioxidant activity, this flavonoid is also capable of exerting an anti-inflammatory action and reducing excitotoxicity [34]. Likewise, Mehta V. et al., observed that orally quercetin treatment $(30 \mathrm{mg} / \mathrm{kg})$, for 21 days, reduced anxiety in animals subjected to unexpected stress, attenuated anhedonia, and improved short- and long-term memory deficits. Quercetin reduced the expression levels of total thiol, TBARS, and NO; conversely, it increased the levels of the antioxidant enzyme CAT. Noteworthy, quercetin treatment also reduced hippocampal gene expression levels for TNF- $\alpha$, IL-6, IL-1 $\beta$, and Cyclooxygenase-2 (COX-2). The cresyl violet staining showed that the hippocampal neurons of the stressed animals showed marked signs of neuronal damage. Conversely, stressed mice treated with quercetin owned neuron morphology similar to the control group. Thus, quercetin may be improving anxiety, depression, and cognitive dysfunction stress-induced, preventing neuronal damage and attenuating oxidative and pro-inflammatory responses [35]. In a similar way to quercetin, quercetin-3- $\alpha$-l-arabinofuranoside (Avicularin), a glycoside of quercetin exerted an anti-depressant effect on a mouse model of depression induced by chronic unpredictable mild stress. Administration of Avicularin $(1.25,2.5$, or $5.0 \mathrm{mg} / \mathrm{kg})$ via gavage for 21 days significantly decreased the immobility time of mice, in a dose-dependent manner. It exerted similar effects obtained in the fluoxetine $(20 \mathrm{mg} / \mathrm{kg})$ group. Avicularin significantly 
reduced the TNF- $\alpha$, IL- 6 , IL- $1 \beta$, inducible NO synthase, and COX-2 that instead were higher in the hippocampi of stressed mice. Moreover, Avicularin exerted anti-inflammatory effects inhibiting the activation of MEK/ERK/nuclear factor- $\mathrm{KB}$ (NF- $\mathrm{KB}$ ) signaling pathway; conversely, it was activated significantly in mice exposed to stress. Similar to fluoxetine, this glycoside of quercetin reduced Bax and Caspase- 3 levels, in a dose-dependent manner, thus reducing neuroinflammation and apoptosis in hippocampus [36]. Ma Z.X. et al. investigated the molecular mechanisms underlying the neuroprotective and antidepressant effects of quercetin in a murine model of unpredictable mild chronic stress. The chronic unpredictable mild stress was induced exposing mice to nine different stressors (physical restraint; horizontal oscillation, noise; clip tail; fasting; crowding; water deprivation; $45^{\circ}$ inclined cage; and overnight illumination) for 21 days. Treatment with quercetin (15 and $30 \mathrm{mg} / \mathrm{kg}$ ), administered via gavage for 21 days, improved depressive-like behaviors. Indeed, the treatment restored stress-induced weight loss, improved locomotor activity in the open field test, and reduced immobility time in the FST. Furthermore, quercetin improved anhedonia, which is important in depressive-type behaviors. Besides, quercetin could induce maturation and survival of neural progenitor cells as demonstrated through immunohistochemical examination of the hippocampus. Indeed, it was observed an increase of the number of doublecortin (DCX)-positive and BrdU/NeuN-double-positive cells, in a dose-dependent manner. Furthermore, this flavonoid raised the protein levels of Forkhead box transcription factor G1 (FoxG1), p-CREB, and BDNF in the hippocampus, which had been downregulated following stress. Therefore, the FoxG1/CREB/BDNF signaling pathway could be used by quercetin to promote adult hippocampal neurogenesis [37]. Also, Donoso F. et al. demonstrated that dietary polyphenols such as quercetin improved dysregulation of HPA in the maternal separation model. Maternal separation is a valid model to investigate the negative effects of early life stress on brain function and structure, related to depressive-like behaviors and anxiety. To induce this stress model, pups were separated from mothers for $3 \mathrm{~h}$, every day for 12 days. After 8 weeks from exposure to early-life stress and 56 days of quercetin dietary $(20 \mathrm{mg} / \mathrm{kg})$, the levels of plasma BDNF increased. Also, dietary ameliorated dysregulation of the HPA axis, lowering the baseline levels of plasma corticosterone compared to the maternal separation model group. In this way, the quercetin diet ameliorated depressive-like behaviors [38]. Consistent with the aforementioned studies, also Sahin T.D. et al. showed that quercetin ameliorated depressive-like behavior in rats subjected to unpredictable chronic mild stress for 5 weeks. Indeed, intraperitoneally injections with quercetin $(30 \mathrm{mg} / \mathrm{kg})$ or resveratrol $(20 \mathrm{mg} / \mathrm{kg}$ ) for 35 days simultaneously to stress exposure, decreased immobility time and increased sucrose consumption. Not unsurprising that the anti-depressive effects of this flavonoid are due to its antioxidant and anti-inflammatory properties. Indeed, quercetin treatment, as also resveratrol, reduced MDA level and increase antioxidant enzymes such as SOD, CAT, and GSH, which are dysregulate in stress conditions. Both flavonoids reduced the NF- $k B$, IL- 6 , TNF- $\alpha$, and IL- $1 \beta$ expression levels. Moreover, the researchers showed that the decreased serum corticosterone levels, restoring the HPA axis could be another mechanism of action used by these flavonoids to exert antidepressive effects [39]. However, also an acute quercetin $(50 \mathrm{mg} / \mathrm{kg}$ ) treatment ( 3 days) along with predatory stress induction ameliorated depressive-like behaviors. In order to stress induce, three mice were placed in the small cage, and the cat, used as a predator/stressor, was placed in the large cage. Mice were exposed to stress for $15 \mathrm{~min}$ for 3 consecutive days. Acute treatment reduced immobility time and improved spatial working memory and voluntary exploration of mice [40].

Zhang J. et al. examined the effects of quercetin-enriched diets, started before, after, or at the same time as exposure to stressors. A quercetin-enriched diet $(2 \mathrm{~g} / \mathrm{kg})$ for 14 days before exposure to stress prevented depressive-like behaviors. The mice were also treated with a dose of quercetin $(0.5 \mathrm{~g} / \mathrm{kg})$ comparable to that contained in a diet rich in fruits and vegetables. Also, this quercetin dose, before stress exposure, improved depressive-like behaviors. Additionally, the quercetin diet started before stress increased neuronal activity 
in the medial prefrontal cortex and hippocampus. Indeed, compared to mice fed a normal diet, the quercetin-enriched diet increased the frequencies of spontaneous excitatory and inhibitory postsynaptic currents both in the medial prefrontal cortex and in the hippocampus. Furthermore, the quercetin-enriched diets prior to stress exposure inhibited the expression of genes related to microglia and astrocyte activation in both the medial prefrontal cortex and hippocampus. Conversely, quercetin-enriched diets administered concurrently and after exposure to stress did not trigger the same antidepressant effects triggered by a long-term diet. Therefore, the data results demonstrate that a long-term diet rich in quercetin or a diet rich in fruits and vegetables could induce antidepressant effects and prevent the damage induced by chronic stress. Furthermore, inhibition of astrocytes and microglia could be a mechanism used by quercetin to regulate neuronal activity and improve depressive-like behaviors [41]. Recently, Guan et al. studied the antidepressantlike effects and potential mechanism of quercetin in chronic unpredictable mild stress rats, measuring the changes of serum elements. Rats were treated with different doses of quercetin $(10$ and $50 \mathrm{mg} / \mathrm{kg}$ ). After 8 weeks of exposure to chronic unpredictable mild stress, the serum of rats was collected in order to analyzed enzyme indicators, antioxidant indicators, and inflammatory cytokines by inductively coupled plasma mass spectrometry. Quercetin $(50 \mathrm{mg} / \mathrm{kg})$ treatment increased the sucrose preference of depressed rats and decreased pro-inflammatory cytokines serum levels. Moreover, compared with the control group, depressed rats showed increased levels of iron, copper, and calcium in serum while the levels of magnesium, zinc, selenium, and cobalt significantly decreased. Treatment with quercetin at a dose of $50 \mathrm{mg} / \mathrm{kg}$ restored the level of these elements. Thus, quercetin, due to its antioxidant and anti-inflammatory properties, exerts regulatory effects on serum elements [42].

\subsection{Quercetin Effects in Animal Models Exposed to Acute Stress}

Inflammation is an important pathogen mechanism involved in the development of depression [130]. Indeed, depressed subjects show elevated levels of pro-inflammatory markers, such as C-reactive protein, IL-6, and a reduced level of BDNF [131,132]. Also, in depressed subjects, a decrease of $\mathrm{BDNF}$ / tropomyosin receptor kinase $\mathrm{B}$ (TrkB) signaling pathway and impaired neuronal plasticity play an important role in the pathogenesis of depressive disorders [133]. In this context, Fang K. et al. evaluated the effects of quercetin ( $95 \%$ of purity), on lipopolysaccharide (LPS)-induced depressive-like behavior and its mechanism of action. LPS is used to induce inflammatory stimuli; however, LPS-treated rats have been shown to exhibit depressive-like behavior. Researchers demonstrated that both quercetin $(40 \mathrm{mg} / \mathrm{kg})$ and ibuprofen $(240 \mathrm{mg} / \mathrm{kg})$ administered via gavage for 14 days improved body-weight gain in rats and ameliorated the impaired LPS-induced neuropsychiatric behaviors including anxiety, depression, and memory impairment. This data highlights the close relationship between inflammation and depression. Moreover, treatment with LPS reduced the protein expression of BDNF, $\mathrm{p}-\operatorname{TrkB} / \operatorname{TrkB}$, triggering receptors expressed on myeloid cells (TREM) 1, Copine 6, and synapsin-1, both in the hippocampus and prefrontal cortex; conversely, the expression of TREM2 was increased. However, quercetin treatment reversed the expression levels of these proteins, similarly to groups treated with ibuprofen and fluoxetine $(5 \mathrm{mg} / \mathrm{kg})$. So quercetin could exert these anti-depressive effects reduced neuroinflammation response and enhancing neuroplasticity [43]. Also, in a model of depressive-like behaviors induced by cancer, quercetin combined to exercise training mediated the anti-depressive effects, reducing inflammatory cytokines, which in turn, in the prefrontal cortex, enhanced BDNF/TrKB $/ \beta$-catenin axis, a major signaling pathway with anti-depressive action. Indeed, after the last injection of 1,2-dimethylhydrazine (DMH) to induce cancer, mice received quercetin $(50 \mathrm{mg} / \mathrm{kg})$ and exercise training for 84 days. The combination of quercetin and exercise ameliorated the DMH-induced depressive-like behaviors. Indeed, compare to mono-treatment groups, this combination treatment reduced the immobility time and enhanced ambulation and rearing counts. The combination treatment also reduced the IL- $1 \beta$ and TNF- $\alpha$ serum and tissue 
levels, which instead increased following DMH injections [44]. In this regard, Wang G. et al. investigated the role of the BDNF-TrkB signaling pathway in hippocampal tissues of estrogen receptor $\alpha$ deficiency-female mice, that induced behaviors similar to depression. Oral administration of quercetin $(100 \mathrm{mg} / \mathrm{kg})$ for 70 days improved the depressive responses in mice. Furthermore, estrogen receptor $\alpha$ deficiency induced a decrease in the number of hippocampal neurons compared to the control group; which conversely, increased following treatment with quercetin. This flavonoid also reduced apoptosis by increasing anti-apoptotic proteins, such as Bcl-2 and reducing pro-apoptotic proteins, such as activated Bax and cleaved caspase-3. Immunoblotting analysis in hippocampal tissue demonstrated that the deficit of the estrogen receptor $\alpha$ significantly decreased BDNF levels and the phosphorylation of its downstream targets such as TrkB, protein kinase B (Akt), and extracellular regulatory protein kinase $1 / 2$ (ERK1/2). Conversely, quercetin significantly increased the expression levels of these proteins, highlighting that the antidepressant effect of quercetin could be mediated by modulation of BDNF-Akt/ERK1/2 signaling [45], as also observed in the study described above [44].

Quercetin is also able to reduce plasma cortisol levels, improving memory deficits and alleviating stress-induced disorders $[30,134]$. Furthermore, as a response to stress, quercetin is able to activate the HPA axis, decreasing the levels of the corticotropin-releasing factor, closely related to the development of factors similar to depression [30]. In this regard, Merzoug S. et al. investigated the benefit of quercetin on depressive-like and anxiety-like behaviors caused by a chemotherapeutic agent that activates the HPA axis, Adriamycin. Quercetin (quercetin dihydrate; $60 \mathrm{mg} / \mathrm{kg}$ ) was intraperitoneally administered 24, 5, and $1 \mathrm{~h}$ before the behavioral tests. Quercetin pre-treatment ameliorated the anxiety-depressivelike behavior induced by Adriamycin, reducing immobility and increasing swimming time. Moreover, Adriamycin increased the plasma corticosterone concentration. Conversely, quercetin restored the corticosterone level, highlighting that, at least in part, its antidepressive effects are due to HPA axis modulation. Moreover, the effect of quercetin could be also associated with its ability to stabilize high levels of glutathione (GSH) and to reduce glutathione-S-transferase (GST) and malondialdehyde (MDA) levels. Additionally, quercetin treatment reversed leucopenia and attenuated lymphopenia and monocytosis in rats pre-treated with Adriamycin, restoring stress-induced immune alterations [46]. Contrary to the results obtained in the previous studies [38,46], Demir E.A. et al. showed that the antidepressant effects of quercetin in diabetics are not due to the involvement of the HPA axis. Streptozotocin-induced diabetes increased the immobility time of mice in the FST, as observed in depressive-like behavior. After 21 days of treatment quercetin at a dose of $50 \mathrm{mg} / \mathrm{kg}$ improved depressive-like behaviors. However, quercetin did not change plasma concentrations of adrenocorticotropic hormone and corticosterone. Instead, the higher dose of quercetin $(100 \mathrm{mg} / \mathrm{kg})$ had not exerted antidepressant effects [47].

Holzmann et al. investigated the antidepressant effects of quercetin in an animal model of depression based on bilateral destruction of the olfactory bulb. Ablation of the olfactory bulb consists of bilateral destruction of the olfactory bulb, that induces behavioral changes similar to depressive symptoms. After 14 days from model induction, the animals were treated with quercetin $(25 \mathrm{mg} / \mathrm{kg})$ or fluoxetine $(10 \mathrm{mg} / \mathrm{kg})$ by mouth for two weeks. Quercetin, like fluoxetine, showed antidepressant effects by reducing hyperactivity in the open field test, immobility in the forced swim and tail suspension tests, and it improved anhedonic behavior in the splash test. The antioxidant effect of quercetin may be related to its ability to restore lipid hydroperoxide levels in the hippocampus, which increased following olfactory bulbectomy. In order to evaluate the involvement of N-methyl-D-aspartate (NMDA)receptors and the L-arginine-NO-cyclic guanosine monophosphate (cGMP) pathway in the antidepressant effect of quercetin, animals not undergoing olfactory bulbectomy were treated with L-arginine, methylene blue, NMDA, 7-nitroindazole, and sildenafil. Treatment with NMDA and L-arginine inhibited the antidepressant effect of quercetin. Moreover, researchers demonstrated that inhibition of NMDA receptors and NO synthesis may mediate the antidepressive effects of quercetin [48]. Also, in the study performed 
by Rinwa P. et al. treatment with quercetin ( 40 and $80 \mathrm{mg} / \mathrm{kg}$ ) for 14 days significantly prevented the behavioral changes induced by olfactory bulbectomy. In this study, quercetin reduced oxidative/nitrosative stress markers such as nitrite and MDA; instead, it increased the levels of GSH, SOD, and CAT. It also reduced neuroinflammation significantly attenuating TNF- $\alpha$ and IL- 6 levels in both the cerebral cortex and hippocampus. Chronic treatment with quercetin significantly, also, reduced caspase-3 activity. Furthermore, this flavonoid decreased the levels of microglial cells, compared to the group of animals undergoing olfactory bulbectomy. Therefore, the antidepressant effects of quercetin could be mediated by the inhibition of microglia. To support this hypothesis, the researchers evaluated the combined effects of quercetin (20 and $40 \mathrm{mg} / \mathrm{kg}$ ) with minocycline $(25 \mathrm{mg} / \mathrm{kg})$, a known inhibitor of microglia. Results' data demonstrated that combined treatment significantly enhanced their antidepressant effects compared to mono-treatment. Therefore, quercetin could attenuate the neuroinflammatory-apoptotic and oxidative-nitrosative stress cascade associated with depressive-like behaviors through inhibition of the microglia pathway [49].

In conclusion, the results of these in vivo studies, summarized in Table 2, showed that quercetin and its glycosides, exerted potential antidepressant effects in several models of depressive-like behaviors, induces by different types of acute or chronic stress (Figure 4).

Table 2. Summary of the preclinical studies that evaluate functional properties of quercetin its glycosides in depressive-like behaviors. Specifically, the table lists the animal models used in the studies, used compounds, the type of treatment, the dosage and the obtained results.

\begin{tabular}{|c|c|c|c|c|c|}
\hline Models & Compounds & Quercetin Dose & Treatments & Results & Ref. \\
\hline \multicolumn{6}{|c|}{ Chronic Stress } \\
\hline $\begin{array}{l}\text { Depressive-like } \\
\text { behaviors model } \\
\text { induced by } \\
\text { immobilization- } \\
\text { stressed in Albino } \\
\text { Wistar mice }\end{array}$ & Quercetin & $20 \mathrm{mg} / \mathrm{kg}$ & $\begin{array}{c}\text { Daily } \\
\text { intraperitoneal } \\
\text { injections for } \\
14 \text { days }\end{array}$ & $\begin{array}{l}\text { Quercetin induced antidepressant and } \\
\text { anxiolytic effects through the reduction } \\
\text { of the stress-induced lipid peroxidation } \\
\text { and increased antioxidant enzymes } \\
\text { such SOD, CAT and GPx. Moreover, } \\
\text { quercetin significantly increased Ach } \\
\text { and reduced 5-HIAA levels in the brain } \\
\text { of stressed mice, ameliorating } \\
\text { serotonergic and cholinergic functions. }\end{array}$ & [32] \\
\hline $\begin{array}{l}\text { Depressive-like } \\
\text { behaviors model } \\
\text { induced by } \\
\text { unpredictable mild } \\
\text { chronic stress in } \\
\text { Swiss Albino mice }\end{array}$ & $\begin{array}{c}\text { Quercetin or } \\
\text { Quercetin } \\
\text { 4'-O-glucoside }\end{array}$ & 10 and $20 \mathrm{mg} / \mathrm{kg}$ & $\begin{array}{c}\text { Daily orally } \\
\text { administration } \\
\text { for } 7 \text { or } 21 \text { days }\end{array}$ & $\begin{array}{l}\text { Quercetin and quercetin } 4^{\prime} \text {-O-glucoside } \\
\text { exerted their antidepressive activity } \\
\text { through decreasing immobility time in } \\
\text { the FST and improve locomotor activity. } \\
\text { Moreover, in a mouse model of } \\
\text { unpredictable mild chronic } \\
\text { stress-induced depressive behavior, } \\
\text { quercetin } 4^{\prime} \text {-O-glucoside exhibited } \\
\text { anti-depressive effects, increasing 5-HT } \\
\text { levels in the brain and reducing ROS } \\
\text { levels and MAO-A activity. }\end{array}$ & [33] \\
\hline $\begin{array}{l}\text { Depressive-like } \\
\text { behavior model } \\
\text { induced by } \\
\text { unpredictable mild } \\
\text { chronic stress in } \\
\text { Swiss Albino mice }\end{array}$ & $\begin{array}{l}\text { Quercetin or } \\
\text { fluoxetine }\end{array}$ & $25 \mathrm{mg} / \mathrm{kg}$ & $\begin{array}{l}\text { Daily orally } \\
\text { administration } \\
\text { for } 28 \text { days }\end{array}$ & $\begin{array}{c}\text { Treatment with quercetin significantly } \\
\text { increased SOD, GSH, catalase and 5-HT } \\
\text { levels as well as reversed glutamate } \\
\text { and increase pro-inflammatory } \\
\text { cytokines TNF- } \alpha \text { and IL- } 6 \text { levels } \\
\text { induced by unpredictable chronic } \\
\text { mild stress. }\end{array}$ & [34] \\
\hline
\end{tabular}


Table 2. Cont.

\begin{tabular}{|c|c|c|c|c|c|}
\hline Models & Compounds & Quercetin Dose & Treatments & Results & Ref. \\
\hline $\begin{array}{l}\text { Depression-like } \\
\text { behaviors model } \\
\text { induced by chronic } \\
\text { unpredicted stress } \\
\text { in Swiss } \\
\text { Albino mice }\end{array}$ & Quercetin & $30 \mathrm{mg} / \mathrm{kg}$ & $\begin{array}{l}\text { Daily orally ad- } \\
\text { ministration } \\
\text { for } 21 \text { days }\end{array}$ & $\begin{array}{l}\text { Quercetin reduced anxiety in animals, } \\
\text { mitigated anhedonia and ameliorated } \\
\text { the short- and long-term memory } \\
\text { deficits. It also decreased levels of total } \\
\text { thiol, TBARS and NO; conversely, it } \\
\text { increased CAT levels. Additionally, } \\
\text { treatment reduced hippocampal gene } \\
\text { expression levels for TNF- } \alpha \text {, IL-6, } \\
\text { IL-1 } \beta, \text { COX-2, and protected neurons } \\
\text { from stress-mediated damage. }\end{array}$ & [35] \\
\hline $\begin{array}{l}\text { Depressive-like } \\
\text { behavior model } \\
\text { induced by } \\
\text { unpredictable mild } \\
\text { chronic stress in } \\
\text { ICR mice }\end{array}$ & $\begin{array}{l}\text { Quercetin or } \\
\text { fluoxetine }\end{array}$ & 15 and $30 \mathrm{mg} / \mathrm{kg}$ & $\begin{array}{c}\text { Daily } \\
\text { administration } \\
\text { via gavage for } \\
21 \text { days }\end{array}$ & $\begin{array}{l}\text { Quercetin, at both doses, ameliorated } \\
\text { the depressive-like behaviors, restoring } \\
\text { stress-induced weight loss, improving } \\
\text { locomotor activity, decreasing } \\
\text { immobility time and improving } \\
\text { anhedonia. It also could induce } \\
\text { maturation and survival of neural } \\
\text { progenitor cells hippocampus. } \\
\text { Moreover, this compound increased } \\
\text { levels of FoxG1, p-CREB and BDNF, } \\
\text { thus it could induce antidepressive } \\
\text { effects via FoxG1/CREB/BDNF } \\
\text { signaling pathway. }\end{array}$ & [37] \\
\hline $\begin{array}{c}\text { Early life } \\
\text { stress-induced } \\
\text { depressive like } \\
\text { behavior in pups } \\
\text { Sprague } \\
\text { Dawley mice }\end{array}$ & Quercetin & $20 \mathrm{mg} / \mathrm{kg}$ & $\begin{array}{l}\text { Dietary } \\
\text { intervention } \\
\text { for } 56 \text { days }\end{array}$ & $\begin{array}{l}\text { Quercetin dietary raised the levels of } \\
\text { plasma BDNF. It also improved HPA } \\
\text { axis dysregulation, reducing } \\
\text { corticosterone plasma levels. Quercetin } \\
\text { also prevented depressive-like } \\
\text { behaviors induced by maternal } \\
\text { separation. }\end{array}$ & [38] \\
\hline $\begin{array}{l}\text { Depressive-like } \\
\text { behavior induced } \\
\text { by unpredictable } \\
\text { chronic mild stress } \\
\text { in Wistar } \\
\text { albino rats }\end{array}$ & $\begin{array}{c}\text { Quercetion or } \\
\text { resveratrol }\end{array}$ & $30 \mathrm{mg} / \mathrm{kg}$ & $\begin{array}{l}\text { Intraperitoneally } \\
\text { injection for } \\
35 \text { days along } \\
\text { with stress } \\
\text { induction }\end{array}$ & $\begin{array}{l}\text { Quercetin and resveratrol reduced } \\
\text { immobility time and increased sucrose } \\
\text { consumption, exerting anti-depressive } \\
\text { effects. Both flavonoids enhanced } \\
\text { antioxidants defense (SOD, CAT, and } \\
\text { GSH) and reduced MDA levels. These } \\
\text { flavonoids also reduced NF-kB and } \\
\text { pro-inflammatory cytokine (IL-6, } \\
\text { TNF- } \alpha \text {, and IL-1 } \beta \text { ) expression levels. } \\
\text { They also restored the HPA axis } \\
\text { decreasing serum corticosterone levels. }\end{array}$ & [39] \\
\hline $\begin{array}{l}\text { Psychological } \\
\text { stress model } \\
\text { induced by } \\
\text { predatory stress in } \\
\text { ICR mice }\end{array}$ & Quercetin & $50 \mathrm{mg} / \mathrm{kg}$ & $\begin{array}{l}\text { Intraperitoneally } \\
\text { injection for } \\
3 \text { days along } \\
\text { with stress } \\
\text { induction }\end{array}$ & $\begin{array}{l}\text { After } 3 \text { days of predatory stress } \\
\text { exposure, quercetin reduced the innate } \\
\text { fear induced by stress. Also, treatment } \\
\text { improved locomotory immobility time } \\
\text { and spatial working memory and } \\
\text { voluntary exploration of mice as } \\
\text { demonstrated by the } Y \text { maze paradigm. }\end{array}$ & {$[40]$} \\
\hline
\end{tabular}


Table 2. Cont.

\begin{tabular}{|c|c|c|c|c|c|}
\hline Models & Compounds & Quercetin Dose & Treatments & Results & Ref. \\
\hline $\begin{array}{c}\text { Depressive-like } \\
\text { behaviors induced } \\
\text { by chronic social } \\
\text { defeat stress in } \\
\text { C57BL/6N mice }\end{array}$ & Quercetin & 0.5 and $2 \mathrm{~g} / \mathrm{kg}$ & $\begin{array}{c}\text { Oral } \\
\text { administration } \\
\text { via the diet }\end{array}$ & $\begin{array}{l}\text { A quercetin-enriched diet }(2 \mathrm{~g} / \mathrm{kg}) \text { for } \\
14 \text { days before exposure to stress } \\
\text { ameliorated depressive-like behaviors } \\
\text { and increased neuronal activity in the } \\
\text { medial prefrontal cortex and } \\
\text { hippocampus. Moreover, } \\
\text { quercetin-enriched diets inhibited the } \\
\text { expression of genes related to microglia } \\
\text { and astrocyte activation in both the } \\
\text { medial prefrontal cortex and } \\
\text { hippocampus. }\end{array}$ & [41] \\
\hline
\end{tabular}

Model of

depression induced by chronic unpredictable mild stress in rats

\section{Quercetin $\quad 10$ and $50 \mathrm{mg} / \mathrm{kg}$}

Daily administration via gavage for 8 weeks
Quercetin $(50 \mathrm{mg} / \mathrm{kg})$ treatment increased the sucrose preference of depressed rats and decreased pro-inflammatory cytokines serum levels. Moreover, it regulated serum levels of iron, copper, calcium, magnesium, zinc, selenium, and cobalt.
Depressive-like behaviors model induced by intraperitoneal injection of LPS in Sprague-Dawley rats
Quercetin, ibuprofen or fluoxetine
Daily administration via gavage for 14 days
Quercetin improved ameliorated the impaired LPS-induced neuropsychiatric behaviors including anxiety, depression and memory impairment. Moreover, treatment with quercetin exerted its anti-depressive actions regulating the protein expression of BDNF, $\mathrm{p}$-TrkB/TrkB, TREM1/TREM2, Copine 6, and synapsin-1, both in the hippocampus and prefrontal cortex.

Quercetin reduced the immobility time and enhanced ambulation and rearing counts, improving the DMH-induced

Depressive-like behaviors induced by $\mathrm{DMH}$ injections in Wistar rats
Quercetin $\quad 50 \mathrm{mg} / \mathrm{kg}$

Daily orally administration for 84 days depressive-like behaviors. Quercetin exerted antidepressive effects decreasing inflammatory cytokines, such as IL- $1 \beta$ and TNF- $\alpha$; which in turn upregulated

$\mathrm{BDNF} / \operatorname{TrKB} / \beta$-catenin signaling.

Treatment ameliorated the depressive responses in estrogen receptor $\alpha$ deficiency-female mice. It also

Depressive-like behaviors induced by estrogen receptor $\alpha$ deficiency in female mice
Daily orally

$$
\text { Quercetin } \quad 100 \mathrm{mg} / \mathrm{kg}
$$
administration for 70 days increased the number of hippocampal neurons and reduced apoptosis. Moreover, quercetin increased the expression levels of BDNF and of its phosphorylation downstream targets such as TrkB, Akt, and ERK1/2, showing that it could exert antidepressive effects modulating this pathway. 
Table 2. Cont.

\begin{tabular}{|c|c|c|c|c|c|}
\hline Models & Compounds & Quercetin Dose & Treatments & Results & Ref. \\
\hline $\begin{array}{l}\text { Anxiety- } \\
\text { depressive-like } \\
\text { behavior model } \\
\text { induced by } \\
\text { intraperitoneal } \\
\text { injection of } \\
\text { Adriamycin in } \\
\text { Wistar rats }\end{array}$ & Quercetin & $60 \mathrm{mg} / \mathrm{kg}$ & $\begin{array}{c}\text { Single } \\
\text { intraperitoneal } \\
\text { injections at } 24, \\
5 \text {, and } 1 \mathrm{~h}\end{array}$ & $\begin{array}{l}\text { Quercetin ameliorated the } \\
\text { anxiety-depressive-like behavior, } \\
\text { restoring the plasma corticosterone } \\
\text { concentration and reducing oxidative } \\
\text { stress. In detail, quercetin restored the } \\
\text { GSH, GST, and MDA levels. Moreover, } \\
\text { quercetin treatment reversed } \\
\text { leucopenia and attenuated } \\
\text { lymphopenia and monocytosis. }\end{array}$ & [46] \\
\hline $\begin{array}{l}\text { Depressive-like } \\
\text { behavior model } \\
\text { induced by } \\
\text { intraperitoneal } \\
\text { injection of } \\
\text { streptozotocin in } \\
\text { Wistar Albino rats }\end{array}$ & Quercetin & 50 and $100 \mathrm{mg} / \mathrm{kg}$ & $\begin{array}{c}\text { Daily } \\
\text { intraperitoneal } \\
\text { injection for } \\
21 \text { days }\end{array}$ & $\begin{array}{l}\text { Quercetin treatment at a dose of } \\
50 \mathrm{mg} / \mathrm{kg} \text { ameliorated depressive-like } \\
\text { behaviors; conversely, the higher dose } \\
\text { did not induce antidepressant effects. } \\
\text { Quercetin did not change the plasmatic } \\
\text { level of adrenocorticotropic hormone } \\
\text { and corticosterone, showing that this } \\
\text { flavonoid exerted antidepressive effects } \\
\text { independent of the HPA axis. }\end{array}$ & [47] \\
\hline $\begin{array}{l}\text { Depression } \\
\text { induced by } \\
\text { olfactory } \\
\text { bulbectomy in } \\
\text { Wistar rats }\end{array}$ & $\begin{array}{c}\text { Quercetin, } \\
\text { fluoxetine } \\
\text { L-arginine, } \\
\text { methylene blue, } \\
\text { NMDA, } \\
\text { 7-nitroindazole, } \\
\text { sildenafil }\end{array}$ & $25 \mathrm{mg} / \mathrm{kg}$ & $\begin{array}{l}\text { Daily orally } \\
\text { administration } \\
\text { for } 14 \text { days }\end{array}$ & $\begin{array}{l}\text { Quercetin exerted antidepressant } \\
\text { effects reducing lipid hydroperoxide } \\
\text { levels in the hippocampus. These } \\
\text { antidepressive effects were reversed } \\
\text { following treatment with NMDA, } \\
\text { L-arginine, and sildenafil. The } \\
\text { administration of methylene blue and } \\
\text { 7-nitroindazole, in combination with } \\
\text { quercetin, showed a quercetin-like } \\
\text { antidepressant effect, highlighting that } \\
\text { anti-depressive effects of quercetin } \\
\text { could be linked to inhibition of NMDA } \\
\text { receptors and NO synthesis. }\end{array}$ & [48] \\
\hline $\begin{array}{l}\text { Depression } \\
\text { induced by } \\
\text { olfactory } \\
\text { bulbectomy in } \\
\text { Wistar rats }\end{array}$ & $\begin{array}{l}\text { Quercetin } \\
\text { and/or } \\
\text { minocycline }\end{array}$ & $\begin{array}{l}20,40 \text { and } \\
80 \mathrm{mg} / \mathrm{kg}\end{array}$ & $\begin{array}{l}\text { Daily orally } \\
\text { administration } \\
\text { for } 14 \text { days }\end{array}$ & $\begin{array}{l}\text { Quercetin ameliorated behavioral } \\
\text { alterations induced by olfactory } \\
\text { bulbectomy, restoring } \\
\text { oxidative/nitrosative stress markers } \\
\text { (such as nitrite, MDA, GSH, SOD, and } \\
\text { CAT). It also reduced } \\
\text { neuroinflammation reducing TNF- } \alpha \\
\text { and IL-6 levels in both the cerebral } \\
\text { cortex and hippocampus. Quercetin } \\
\text { also reduced caspase-3 activity. } \\
\text { Quercetin could exert its } \\
\text { anti-depressive effects by reducing } \\
\text { microglial activation. }\end{array}$ & [49] \\
\hline
\end{tabular}

SOD, superoxide dismutase; CAT, catalase; GPx, glutathione peroxidase; Ach, acetylcholine; 5-HIAA, 5-hydroxyindoleacetic acid; FST; forced swim test; ROS, reactive oxygen species; 5-HT, 5-hydroxytryptamine; MAO-A, monoamine oxidase-A; IL, interleukin; TNF- $\alpha$, tumor necrosis factor- $\alpha$; TBARS, thiobarbituric acid reactive species; NO, nitric oxide; COX-2, Cyclooxygenase-2; NF- $\mathrm{kB}$, nuclear factor- $\mathrm{kB}$; GSH, glutathione; GST, glutathione-S-transferase; MDA, malondialdehyde; LPS, lipopolysaccharide; TrkB, tropomyosin receptor kinase B; TREM, triggering receptors expressed on myeloid cells; BDNF, brain-derived neutrophic factor; DMH, 1,2-dimethylhydrazine; Akt, protein kinase B; ERK1/2, extracellular regulatory protein kinase 1/2; FoxG1, Forkhead box transcription factor G1; HPA, Hypothalamic-Pituitary-Adrenal; NMDA, N-methyl-D-aspartate. 


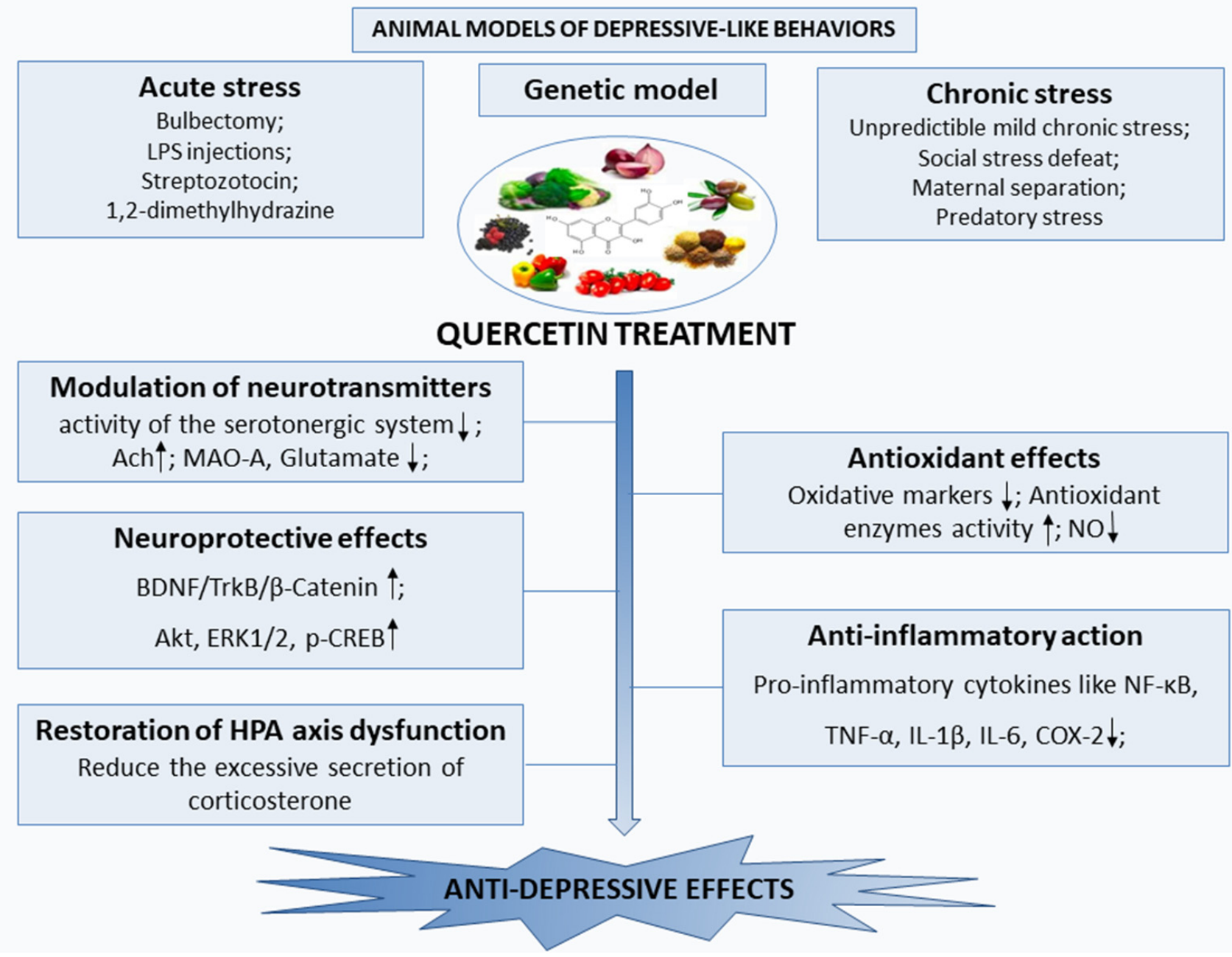

Figure 4. The image graphically summarizes the main mechanisms of action proposed to mediate the antidepressive effects of quercetin. The image of quercetin was created using PubChem (https:/ / pubchem.ncbi.nlm.nih.gov/edit3/index.html/, accessed on 21 June 2021). Ach, acetylcholine; MAO-A, monoamine oxidase-A; NO, nitric oxide; BDNF, brain-derived neutrophic factor; TrkB, tropomyosin receptor kinase B; Akt, protein kinase B; ERK1/2, extracellular regulatory protein kinase1/2; NF- $\mathrm{B}$, nuclear factor- $\mathrm{kB}$; TNF- $\alpha$, tumor necrosis factor- $\alpha$; IL, interleukin; COX-2, Cyclooxygenase-2; HPA, Hypothalamic-Pituitary-Adrenal.

\section{Conclusions}

Quercetin exerts its antidepressant effects by modulating the levels of neurotransmitters. This flavonoid protects against stress, stimulating neurogenesis and neuronal plasticity increasing the BNDF/TrkB signaling activity. Moreover, quercetin improves depressive-like behaviors attenuating inflammatory response, enhancing the activity of antioxidant enzymes, decreasing markers of oxidative stress, and improving alterations of the HPA axis. These findings suggest that natural compounds such as quercetin could be supportive therapy for improving motor and cognitive activity in depressed states.

Author Contributions: Conceptualization, E.M. and P.B.; writing-original draft preparation, S.S.; writing-review and editing, E.M.; supervision, E.M.; funding acquisition, P.B. All authors have read and agreed to the published version of the manuscript.

Funding: This study was supported by Current Research Funds 2021, Ministry of Health, Italy.

Institutional Review Board Statement: Not applicable.

Informed Consent Statement: Not applicable. 
Data Availability Statement: No new data were created or analyzed in this study. Data sharing is not applicable to this article.

Acknowledgments: The authors would like to thank the Ministry of Health, Italy.

Conflicts of Interest: The authors declare no conflict of interest.

\section{References}

1. Mahati, K.; Bhagya, V.; Christofer, T.; Sneha, A.; Rao, B.S. Enriched environment ameliorates depression-induced cognitive deficits and restores abnormal hippocampal synaptic plasticity. Neurobiol. Learn. Mem. 2016, 134 Pt B, 379-391. [CrossRef]

2. McIntyre, R.S.; Cha, D.S.; Soczynska, J.K.; Woldeyohannes, H.O.; Gallaugher, L.A.; Kudlow, P.; Alsuwaidan, M.; Baskaran, A. Cognitive deficits and functional outcomes in major depressive disorder: Determinants, substrates, and treatment interventions. Depress. Anxiety 2013, 30, 515-527. [CrossRef]

3. Frodl, T.; Reinhold, E.; Koutsouleris, N.; Reiser, M.; Meisenzahl, E.M. Interaction of childhood stress with hippocampus and prefrontal cortex volume reduction in major depression. J. Psychiatr. Res. 2010, 44, 799-807. [CrossRef] [PubMed]

4. Desmyter, S.; van Heeringen, C.; Audenaert, K. Structural and functional neuroimaging studies of the suicidal brain. Prog. Neuropsychopharmacol. Biol. Psychiatry 2011, 35, 796-808. [CrossRef] [PubMed]

5. Pittenger, C.; Duman, R.S. Stress, depression, and neuroplasticity: A convergence of mechanisms. Neuropsychopharmacology 2008, 33, 88-109. [CrossRef]

6. Pariante, C.M.; Miller, A.H. Glucocorticoid receptors in major depression: Relevance to pathophysiology and treatment. Biol. Psychiatry 2001, 49, 391-404. [CrossRef]

7. Smith, S.M.; Vale, W.W. The role of the hypothalamic-pituitary-adrenal axis in neuroendocrine responses to stress. Dialogues Clin. Neurosci. 2006, 8, 383-395. [PubMed]

8. Kendler, K.S.; Karkowski, L.M.; Prescott, C.A. Causal relationship between stressful life events and the onset of major depression. Am. J. Psychiatry 1999, 156, 837-841. [CrossRef] [PubMed]

9. Maes, M.; Galecki, P.; Chang, Y.S.; Berk, M. A review on the oxidative and nitrosative stress (O\&NS) pathways in major depression and their possible contribution to the (neuro)degenerative processes in that illness. Prog. Neuro-Psychopharmacol. Biol. Psychiatry 2011, 35, 676-692.

10. Racagni, G.; Popoli, M. The pharmacological properties of antidepressants. Int. Clin. Psychopharmacol. 2010, 25, 117-131. [CrossRef] [PubMed]

11. Dantzer, R.; O'Connor, J.C.; Freund, G.G.; Johnson, R.W.; Kelley, K.W. From inflammation to sickness and depression: When the immune system subjugates the brain. Nat. Rev. Neurosci. 2008, 9, 46-57. [CrossRef] [PubMed]

12. Raison, C.L.; Capuron, L.; Miller, A.H. Cytokines sing the blues: Inflammation and the pathogenesis of depression. Trends Immunol. 2006, 27, 24-31. [CrossRef] [PubMed]

13. Dhir, A. Investigational drugs for treating major depressive disorder. Expert Opin. Investig. Drugs 2017, 26, 9-24. [CrossRef] [PubMed]

14. Falzon, C.C.; Balabanova, A. Phytotherapy: An Introduction to Herbal Medicine. Prim. Care 2017, 44, 217-227. [CrossRef] [PubMed]

15. Bakre, A.G.; Olayemi, J.O.; Ojo, O.R.; Odusanya, S.T.; Agu, G.A.; Aderibigbe, A.O. Antidepressant-like effect of ethanol extract of Blighia unijugata Bak. (Sapindaceae) leaves in acute and chronic models of depression in mice. Niger. J. Physiol. Sci. 2019, 34, 191-199.

16. Chavez-Morales, Y.; Jimenez-Ferrer, E.; Martinez-Hernandez, G.B.; Tortoriello, J.; Roman-Ramos, R.; Zamilpa, A.; Herrera-Ruiz, M. Effect of Standardized Fractions and Tiliroside from Leaves of Tilia americana on Depression Tests in Mice. Iran. J. Pharm. Res. 2019, 18, 1931-1946. [PubMed]

17. Dovichi, S.; Lajolo, F. Flavonoid and Their Relationship to Diseases of The Central Nervous System. J. Braz. Sociaty Food Nutr. Sao Paulo 2011, 36, 123-135.

18. Gonzalez-Aguilar, G.; Robles-Sánchez, R.M.; Martínez-Téllez, M.A.; Olivas, G.I.; Alvarez-Parrilla, E.; De La Rosa, L.A. Bioactive compounds in fruits: Health benefits and effect of storage conditions. Stewart Postharvest Rev. 2008, 4, 1-10.

19. Havsteen, B.H. The biochemistry and medical significance of the flavonoids. Pharmacol. Ther. 2002, 96, 67-202. [CrossRef]

20. Manach, C.; Scalbert, A.; Morand, C.; Remesy, C.; Jimenez, L. Polyphenols: Food sources and bioavailability. Am. J. Clin. Nutr. 2004, 79, 727-747. [CrossRef]

21. Heo, H.J.; Lee, C.Y. Protective effects of quercetin and vitamin C against oxidative stress-induced neurodegeneration. J. Agric. Food Chem. 2004, 52, 7514-7517. [CrossRef]

22. Youdim, K.A.; Shukitt-Hale, B.; Joseph, J.A. Flavonoids and the brain: Interactions at the blood-brain barrier and their physiological effects on the central nervous system. Free Radic. Biol. Med. 2004, 37, 1683-1693. [CrossRef] [PubMed]

23. Dok-Go, H.; Lee, K.H.; Kim, H.J.; Lee, E.H.; Lee, J.; Song, Y.S.; Lee, Y.H.; Jin, C.; Lee, Y.S.; Cho, J. Neuroprotective effects of antioxidative flavonoids, quercetin, (+)-dihydroquercetin and quercetin 3-methyl ether, isolated from Opuntia ficus-indica var. saboten. Brain Res. 2003, 965, 130-136. [CrossRef]

24. Haleagrahara, N.; Radhakrishnan, A.; Lee, N.; Kumar, P. Flavonoid quercetin protects against swimming stress-induced changes in oxidative biomarkers in the hypothalamus of rats. Eur. J. Pharm. 2009, 621, 46-52. [CrossRef] [PubMed] 
25. Paulke, A.; Schubert-Zsilavecz, M.; Wurglics, M. Determination of St. John's wort flavonoid-metabolites in rat brain through high performance liquid chromatography coupled with fluorescence detection. J. Chromatogr. B Anal. Technol. Biomed. Life Sci. 2006, 832, 109-113. [CrossRef] [PubMed]

26. Cho, J.Y.; Kim, I.S.; Jang, Y.H.; Kim, A.R.; Lee, S.R. Protective effect of quercetin, a natural flavonoid against neuronal damage after transient global cerebral ischemia. Neurosci. Lett. 2006, 404, 330-335. [CrossRef]

27. Rojas, P.; Serrano-Garcia, N.; Medina-Campos, O.N.; Pedraza-Chaverri, J.; Ogren, S.O.; Rojas, C. Antidepressant-like effect of a Ginkgo biloba extract (EGb761) in the mouse forced swimming test: Role of oxidative stress. Neurochem. Int. 2011, 59, 628-636. [CrossRef]

28. Sakakibara, H.; Yoshino, S.; Kawai, Y.; Terao, J. Antidepressant-like effect of onion (Allium cepa L.) powder in a rat behavioral model of depression. Biosci. Biotechnol. Biochem. 2008, 72, 94-100. [CrossRef]

29. Bhutada, P.; Mundhada, Y.; Bansod, K.; Ubgade, A.; Quazi, M.; Umathe, S.; Mundhada, D. Reversal by quercetin of corticotrophin releasing factor induced anxiety- and depression-like effect in mice. Prog. Neuropsychopharmacol. Biol. Psychiatry 2010, 34, 955-960. [CrossRef]

30. Kawabata, K.; Kawai, Y.; Terao, J. Suppressive effect of quercetin on acute stress-induced hypothalamic-pituitary-adrenal axis response in Wistar rats. J. Nutr. Biochem. 2010, 21, 374-380. [CrossRef]

31. Moher, D.; Liberati, A.; Tetzlaff, J.; Altman, D.G.; Group, P. Preferred reporting items for systematic reviews and meta-analyses: The PRISMA statement. PLoS Med. 2009, 6, e1000097. [CrossRef] [PubMed]

32. Samad, N.; Saleem, A.; Yasmin, F.; Shehzad, M.A. Quercetin protects against stress-induced anxiety- and depression-like behavior and improves memory in male mice. Physiol. Res. 2018, 67, 795-808. [CrossRef]

33. Singh, V.; Chauhan, G.; Shri, R. Anti-depressant like effects of quercetin 4'-O-glucoside from Allium cepa via regulation of brain oxidative stress and monoamine levels in mice subjected to unpredictable chronic mild stress. Nutr. Neurosci. 2021, 24, 35-44. [CrossRef] [PubMed]

34. Khan, K.; Najmi, A.; Akhtar, M. A Natural Phenolic Compound Quercetin Showed the Usefulness by Targeting Inflammatory, Oxidative Stress Markers and Augment 5-HT Levels in One of the Animal Models of Depression in Mice. Drug Res. 2019, 69, 392-400. [CrossRef]

35. Mehta, V.; Parashar, A.; Udayabanu, M. Quercetin prevents chronic unpredictable stress induced behavioral dysfunction in mice by alleviating hippocampal oxidative and inflammatory stress. Physiol. Behav. 2017, 171, 69-78. [CrossRef] [PubMed]

36. Shen, Z.; Xu, Y.; Jiang, X.; Wang, Z.; Guo, Y.; Pan, W.; Hou, J. Avicularin Relieves Depressive-Like Behaviors Induced by Chronic Unpredictable Mild Stress in Mice. Med. Sci. Monit. 2019, 25, 2777-2784. [CrossRef]

37. Ma, Z.X.; Zhang, R.Y.; Rui, W.J.; Wang, Z.Q.; Feng, X. Quercetin alleviates chronic unpredictable mild stress-induced depressivelike behaviors by promoting adult hippocampal neurogenesis via FoxG1/CREB/BDNF signaling pathway. Behav. Brain Res. 2021, 406, 113245. [CrossRef]

38. Donoso, F.; Egerton, S.; Bastiaanssen, T.F.S.; Fitzgerald, P.; Gite, S.; Fouhy, F.; Ross, R.P.; Stanton, C.; Dinan, T.G.; Cryan, J.F. Polyphenols selectively reverse early-life stress-induced behavioural, neurochemical and microbiota changes in the rat. Psychoneuroendocrinology 2020, 116, 104673. [CrossRef]

39. Sahin, T.D.; Gocmez, S.S.; Duruksu, G.; Yazir, Y.; Utkan, T. Resveratrol and quercetin attenuate depressive-like behavior and restore impaired contractility of vas deferens in chronic stress-exposed rats: Involvement of oxidative stress and inflammation. Naunyn Schmiedebergs Arch. Pharm. 2020, 393, 761-775. [CrossRef]

40. Anggreini, P.; Ardianto, C.; Rahmadi, M.; Khotib, J. Quercetin attenuates acute predator stress exposure-evoked innate fear and behavioral perturbation. J. Basic Clin. Physiol. Pharm. 2019, 30. [CrossRef]

41. Zhang, J.; Ning, L.; Wang, J. Dietary quercetin attenuates depressive-like behaviors by inhibiting astrocyte reactivation in response to stress. Biochem. Biophys. Res. Commun. 2020, 533, 1338-1346. [CrossRef] [PubMed]

42. Guan, T.; Cao, C.; Hou, Y.; Li, Y.; Wei, X.; Li, S.; Jia, S.; Zhao, X. Effects of quercetin on the alterations of serum elements in chronic unpredictable mild stress-induced depressed rats. Biometals 2021, 34, 589-602. [CrossRef] [PubMed]

43. Fang, K.; Li, H.R.; Chen, X.X.; Gao, X.R.; Huang, L.L.; Du, A.Q.; Jiang, C.; Li, H.; Ge, J.F. Quercetin Alleviates LPS-Induced Depression-Like Behavior in Rats via Regulating BDNF-Related Imbalance of Copine 6 and TREM1/2 in the Hippocampus and PFC. Front. Pharm. 2019, 10, 1544. [CrossRef] [PubMed]

44. Sadighparvar, S.; Darband, S.G.; Yousefi, B.; Kaviani, M.; Ghaderi-Pakdel, F.; Mihanfar, A.; Babaei, G.; Mobaraki, K.; Majidinia, M. Combination of quercetin and exercise training attenuates depression in rats with 1,2-dimethylhydrazine-induced colorectal cancer: Possible involvement of inflammation and BDNF signalling. Exp. Physiol. 2020, 105, 1598-1609. [CrossRef]

45. Wang, G.; Li, Y.; Lei, C.; Lei, X.; Zhu, X.; Yang, L.; Zhang, R. Quercetin exerts antidepressant and cardioprotective effects in estrogen receptor alpha-deficient female mice via BDNF-AKT/ERK1/2 signaling. J. Steroid Biochem. Mol. Biol. 2021, $206,105795$. [CrossRef]

46. Merzoug, S.; Toumi, M.L.; Tahraoui, A. Quercetin mitigates Adriamycin-induced anxiety- and depression-like behaviors, immune dysfunction, and brain oxidative stress in rats. Naunyn Schmiedebergs Arch. Pharm. 2014, 387, 921-933. [CrossRef]

47. Demir, E.A.; Gergerlioglu, H.S.; Oz, M. Antidepressant-like effects of quercetin in diabetic rats are independent of hypothalamicpituitary-adrenal axis. Acta Neuropsychiatr. 2016, 28, 23-30. [CrossRef] 
48. Holzmann, I.; da Silva, L.M.; Correa da Silva, J.A.; Steimbach, V.M.; de Souza, M.M. Antidepressant-like effect of quercetin in bulbectomized mice and involvement of the antioxidant defenses, and the glutamatergic and oxidonitrergic pathways. Pharm. Biochem. Behav. 2015, 136, 55-63. [CrossRef]

49. Rinwa, P.; Kumar, A. Quercetin suppress microglial neuroinflammatory response and induce antidepressent-like effect in olfactory bulbectomized rats. Neuroscience 2013, 255, 86-98. [CrossRef]

50. Nuutila, A.M.; Puupponen-Pimia, R.; Aarni, M.; Oksman-Caldentey, K.M. Comparison of antioxidant activities of onion and garlic extracts by inhibition of lipid peroxidation and radical scavenging activity. Food Chem. 2003, 81, 485-493. [CrossRef]

51. Singh, J.; Upadhyay, A.K.; Prasad, K.; Bahadur, A.; Rai, M. Variability of carotenes, vitamin C, E and phenolics in Brassica vegetables. J. Food Compos. Anal. 2007, 20, 106-112. [CrossRef]

52. Vallejo, F.; Tomas-Barberan, F.; García-Viguera, C. Effect of climatic and sulphur fertilisation conditions, on phenolic compounds and vitamin C, in the inflorescences of eight broccoli cultivars. Eur. Food Res. Technol. 2003, 216, 395-401. [CrossRef]

53. Gliszczynska-Swiglo, A.; Kaluzewicz, A.; Lemanska, K.; Knaflewski, M.; Tyrakowska, B. The effect of solar radiation on the flavonol content in broccoli inflorescence. Food Chem. 2007, 100, 241-245. [CrossRef]

54. Mogren, L.M.; Olsson, M.E.; Gertsson, U.E. Effects of cultivar, lifting time and nitrogen fertiliser level on quercetin content in onion(Allium cepa L.) at lifting. J. Sci. Food Agric. 2007, 87, 470-476. [CrossRef]

55. Patil, B.S.; Pike, L.M.; Hamilton, B.K. Changes in Quercetin Concentration in Onion (Allium cepa L.) Owing to Location, Growth Stage and Soil Type. New Phytol. 1995, 130, 349-355. [CrossRef]

56. Aaby, K.; Wrolstad, R.E.; Ekeberg, D.; Skrede, G. Polyphenol composition and antioxidant activity in strawberry purees; impact of achene level and storage. J. Agric. Food Chem. 2007, 55, 5156-5166. [CrossRef] [PubMed]

57. Rawson, A.; Koidis, A.; Rai, D.K.; Tuohy, M.; Brunton, N. Influence of Sous Vide and water immersion processing on polyacetylene content and instrumental color of parsnip (Pastinaca sativa) disks. J. Agric. Food Chem. 2010, 58, 7740-7747. [CrossRef]

58. Volden, J.; Bengtsson, G.B.; Wicklund, T. Glucosinolates, L-ascorbic acid, total phenols, anthocyanins, antioxidant capacities and colour in cauliflower (Brassica oleracea L. ssp. botrytis); effects of long-term freezer storage. Food Chem. 2009, 112, 967-976. [CrossRef]

59. Rodrigues, A.; Pérez-Gregorio, M.; García-Falcón, M.; Simal-Gándara, J. Effect of curing and cooking on flavonols and anthocyanins in traditional varieties of onion bulbs. Food Res. Int. 2009, 42, 1331-1336. [CrossRef]

60. Gennaro, L.; Leonardi, C.; Esposito, F.; Salucci, M.; Maiani, G.; Quaglia, G.; Fogliano, V. Flavonoid and carbohydrate contents in Tropea red onions: Effects of homelike peeling and storage. J. Agric. Food Chem. 2002, 50, 1904-1910. [CrossRef]

61. Dinelli, G.; Bonetti, A.; Minelli, M.; Marotti, I.; Catizone, P.; Mazzanti, A. Content of flavonols in Italian bean (Phaseolus vulgaris L.) ecotypes. Food Chem. 2006, 99, 105-114. [CrossRef]

62. Elizabeth, R.G.N.; Annete, H.; Francisco, G.L.R.; Javier, I.P.F.; Graciela, Z.G.; Alberto, G.I.J. Antioxidant and antimutagenic activity of phenolic compounds in three different colour groups of common bean cultivars (Phaseolus vulgaris). Food Chem. 2007, 103, 521-527.

63. Manach, C.; Mazur, A.; Scalbert, A. Polyphenols and prevention of cardiovascular diseases. Curr. Opin. Lipidol. 2005, 16, 77-84. [CrossRef] [PubMed]

64. Mitchell, A.E.; Hong, Y.J.; Koh, E.; Barrett, D.M.; Bryant, D.E.; Denison, R.F.; Kaffka, S. Ten-year comparison of the influence of organic and conventional crop management practices on the content of flavonoids in tomatoes. J. Agric. Food Chem. 2007, 55, 6154-6159. [CrossRef] [PubMed]

65. Harwood, M.; Danielewska-Nikiel, B.; Borzelleca, J.F.; Flamm, G.W.; Williams, G.M.; Lines, T.C. A critical review of the data related to the safety of quercetin and lack of evidence of in vivo toxicity, including lack of genotoxic/carcinogenic properties. Food Chem. Toxicol. 2007, 45, 2179-2205. [CrossRef] [PubMed]

66. Heijnen, C.G.; Haenen, G.R.; Oostveen, R.M.; Stalpers, E.M.; Bast, A. Protection of flavonoids against lipid peroxidation: The structure activity relationship revisited. Free Radic. Res. 2002, 36, 575-581. [CrossRef] [PubMed]

67. Sadzak, A.; Mravljak, J.; Maltar-Strmecki, N.; Arsov, Z.; Baranovic, G.; Erceg, I.; Kriechbaum, M.; Strasser, V.; Pribyl, J.; Segota, S. The Structural Integrity of the Model Lipid Membrane during Induced Lipid Peroxidation: The Role of Flavonols in the Inhibition of Lipid Peroxidation. Antioxidants 2020, 9, 430. [CrossRef] [PubMed]

68. Luiz da Silva, E.; Tsushida, T.; Terao, J. Inhibition of mammalian 15-lipoxygenase-dependent lipid peroxidation in low-density lipoprotein by quercetin and quercetin monoglucosides. Arch. Biochem. Biophys. 1998, 349, 313-320. [CrossRef]

69. Yamamoto, N.; Moon, J.H.; Tsushida, T.; Nagao, A.; Terao, J. Inhibitory effect of quercetin metabolites and their related derivatives on copper ion-induced lipid peroxidation in human low-density lipoprotein. Arch. Biochem. Biophys. 1999, 372, 347-354. [CrossRef] [PubMed]

70. Rubio-Ruiz, M.E.; Guarner-Lans, V.; Cano-Martinez, A.; Diaz-Diaz, E.; Manzano-Pech, L.; Gamas-Magana, A.; Castrejon-Tellez, V.; Tapia-Cortina, C.; Perez-Torres, I. Resveratrol and Quercetin Administration Improves Antioxidant DEFENSES and reduces Fatty Liver in Metabolic Syndrome Rats. Molecules 2019, 24, 1297. [CrossRef]

71. Korkina, L.G.; Afanas'ev, I.B. Antioxidant and chelating properties of flavonoids. Adv. Pharm. 1997, 38, $151-163$.

72. de Souza, R.F.; De Giovani, W.F. Antioxidant properties of complexes of flavonoids with metal ions. Redox Rep. 2004, 9, 97-104. [CrossRef] 
73. Ferrali, M.; Signorini, C.; Caciotti, B.; Sugherini, L.; Ciccoli, L.; Giachetti, D.; Comporti, M. Protection against oxidative damage of erythrocyte membrane by the flavonoid quercetin and its relation to iron chelating activity. FEBS Lett. 1997, 416, 123-129. [CrossRef]

74. Kessler, R.C. The effects of stressful life events on depression. Annu. Rev. Psychol. 1997, 48, 191-214. [CrossRef] [PubMed]

75. Ng, F.; Berk, M.; Dean, O.; Bush, A.I. Oxidative stress in psychiatric disorders: Evidence base and therapeutic implications. Int. J. Neuropsychopharmacol. 2008, 11, 851-876. [CrossRef] [PubMed]

76. Chwastiak, L.A.; Von Korff, M. Disability in depression and back pain: Evaluation of the World Health Organization Disability Assessment Schedule (WHO DAS II) in a primary care setting. J. Clin. Epidemiol. 2003, 56, 507-514. [CrossRef]

77. Chand, S.P.; Arif, H. Depression; StatPearls Publishing: Treasure Island, FL, USA, 2021.

78. McCoy, C.R.; Jackson, N.L.; Day, J.; Clinton, S.M. Genetic predisposition to high anxiety- and depression-like behavior coincides with diminished DNA methylation in the adult rat amygdala. Behav. Brain Res. 2017, 320, 165-178. [CrossRef]

79. Kohli, M.A.; Lucae, S.; Saemann, P.G.; Schmidt, M.V.; Demirkan, A.; Hek, K.; Czamara, D.; Alexander, M.; Salyakina, D.; Ripke, S.; et al. The neuronal transporter gene SLC6A15 confers risk to major depression. Neuron 2011, 70, 252-265. [CrossRef]

80. Zanier-Gomes, P.H.; de Abreu Silva, T.E.; Zanetti, G.C.; Benati, E.R.; Pinheiro, N.M.; Murta, B.M.; Crema, V.O. Depressive behavior induced by social isolation of predisposed female rats. Physiol. Behav. 2015, 151, 292-297. [CrossRef] [PubMed]

81. Hirschfeld, R.M. History and evolution of the monoamine hypothesis of depression. J. Clin. Psychiatry 2000, 61 (Suppl. S6), 4-6.

82. Nutt, D.J. Relationship of neurotransmitters to the symptoms of major depressive disorder. J. Clin. Psychiatry 2008, 69 (Suppl. SE1), 4-7. [PubMed]

83. Gorwood, P. Neurobiological mechanisms of anhedonia. Dialogues Clin. Neurosci. 2008, 10, 291-299.

84. Newberg, A.; Amsterdam, J.; Shults, J. Dopamine transporter density may be associated with the depressed affect in healthy subjects. Nucl. Med. Commun. 2007, 28, 3-6. [CrossRef]

85. Brietzke, E.; Stertz, L.; Fernandes, B.S.; Kauer-Sant'anna, M.; Mascarenhas, M.; Escosteguy Vargas, A.; Chies, J.A.; Kapczinski, F. Comparison of cytokine levels in depressed, manic and euthymic patients with bipolar disorder. J. Affect. Disord. 2009, 116, 214-217. [CrossRef]

86. Chen, Y.; Ouyang, J.; Liu, S.; Zhang, S.; Chen, P.; Jiang, T. The Role of Cytokines in the Peripheral Blood of Major Depressive Patients. Clin. Lab. 2017, 63, 1207-1212. [CrossRef]

87. Fernandes, B.S.; Berk, M.; Turck, C.W.; Steiner, J.; Goncalves, C.A. Decreased peripheral brain-derived neurotrophic factor levels are a biomarker of disease activity in major psychiatric disorders: A comparative meta-analysis. Mol. Psychiatry 2014, 19, 750-751. [CrossRef]

88. Werner, F.M.; Covenas, R. Classical neurotransmitters and neuropeptides involved in major depression: A review. Int. J. Neurosci. 2010, 120, 455-470. [CrossRef] [PubMed]

89. Grippo, A.J.; Johnson, A.K. Stress, depression and cardiovascular dysregulation: A review of neurobiological mechanisms and the integration of research from preclinical disease models. Stress 2009, 12, 1-21. [CrossRef]

90. Czarny, P.; Wigner, P.; Galecki, P.; Sliwinski, T. The interplay between inflammation, oxidative stress, DNA damage, DNA repair and mitochondrial dysfunction in depression. Prog. Neuro-Psychopharmacol. Biol. Psychiatry 2018, 80, 309-321. [CrossRef]

91. Bishop, A.; Anderson, J.E. NO signaling in the CNS: From the physiological to the pathological. Toxicology 2005, 208, 193-205. [CrossRef] [PubMed]

92. Drevets, W.C.; Savitz, J.; Trimble, M. The subgenual anterior cingulate cortex in mood disorders. CNS Spectr. 2008, 13, 663-681. [CrossRef]

93. Sen, S.; Duman, R.; Sanacora, G. Serum brain-derived neurotrophic factor, depression, and antidepressant medications: Metaanalyses and implications. Biol. Psychiatry 2008, 64, 527-532. [CrossRef]

94. Caraci, F.; Spampinato, S.F.; Morgese, M.G.; Tascedda, F.; Salluzzo, M.G.; Giambirtone, M.C.; Caruso, G.; Munafo, A.; Torrisi, S.A.; Leggio, G.M.; et al. Neurobiological links between depression and AD: The role of TGF-beta1 signaling as a new pharmacological target. Pharm. Res. 2018, 130, 374-384. [CrossRef]

95. Myint, A.M.; Leonard, B.E.; Steinbusch, H.W.; Kim, Y.K. Th1, Th2, and Th3 cytokine alterations in major depression. J. Affect. Disord. 2005, 88, 167-173. [CrossRef]

96. Musil, R.; Schwarz, M.J.; Riedel, M.; Dehning, S.; Cerovecki, A.; Spellmann, I.; Arolt, V.; Muller, N. Elevated macrophage migration inhibitory factor and decreased transforming growth factor-beta levels in major depression-No influence of celecoxib treatment. J. Affect. Disord. 2011, 134, 217-225. [CrossRef]

97. Corbineau, S.; Breton, M.; Mialet-Perez, J.; Costemale-Lacoste, J.F. Major depression and heart failure: Interest of monoamine oxidase inhibitors. Int. J. Cardiol. 2017, 247, 1-6. [CrossRef] [PubMed]

98. Medrihan, L.; Sagi, Y.; Inde, Z.; Krupa, O.; Daniels, C.; Peyrache, A.; Greengard, P. Initiation of Behavioral Response to Antidepressants by Cholecystokinin Neurons of the Dentate Gyrus. Neuron 2017, 95, 564-576 e564. [CrossRef] [PubMed]

99. Khalid, M.M.; Waseem, M. Tricyclic Antidepressant Toxicity; StatPearls Publishing: Treasure Island, FL, USA, 2021.

100. Bradley, A.J.; Lenox-Smith, A.J. Does adding noradrenaline reuptake inhibition to selective serotonin reuptake inhibition improve efficacy in patients with depression? A systematic review of meta-analyses and large randomised pragmatic trials. J. Psychopharmacol. 2013, 27, 740-758. [CrossRef] 
101. Kumar, U.; Medel-Matus, J.S.; Redwine, H.M.; Shin, D.; Hensler, J.G.; Sankar, R.; Mazarati, A. Effects of selective serotonin and norepinephrine reuptake inhibitors on depressive- and impulsive-like behaviors and on monoamine transmission in experimental temporal lobe epilepsy. Epilepsia 2016, 57, 506-515. [CrossRef] [PubMed]

102. Wang, P.P.; Fu, T.T.; Zhang, X.Y.; Yang, F.Y.; Zheng, G.X.; Xue, W.W.; Chen, Y.Z.; Yao, X.J.; Zhu, F. Differentiating physicochemical properties between NDRIs and sNRIs clinically important for the treatment of ADHD. Biochim. Biophys. Acta Gen. Subj. 2017, 1861, 2766-2777. [CrossRef] [PubMed]

103. Moret, C.; Isaac, M.; Briley, M. Problems associated with long-term treatment with selective serotonin reuptake inhibitors. J. Psychopharmacol. 2009, 23, 967-974. [CrossRef]

104. Czéh, B.; Fuchs, E.; Wiborg, O.; Simon, M. Animal models of major depression and their clinical implications. Prog. NeuroPsychopharmacol. Biol. Psychiatry 2016, 64, 293-310. [CrossRef]

105. Duman, C.H. Models of depression. Vitam. Horm. 2010, 82, 1-21.

106. Deussing, J.M. Animal models of depression. Drug Discov. Today Dis. Models 2006, 3, 375-383. [CrossRef]

107. Cairncross, K.; Cox, B.; Forster, C.; Wren, A.F. A new model for the detection of antidepressant drugs: Olfactory bulbectomy in the rat compared with existing models. J. Pharmacol. Methods 1978, 1, 131-143. [CrossRef]

108. Steru, L.; Chermat, R.; Thierry, B.; Simon, P. The tail suspension test: A new method for screening antidepressants in mice. Psychopharmacology 1985, 85, 367-370. [CrossRef]

109. Porsolt, R.D.; Le Pichon, M.; Jalfre, M. Depression: A new animal model sensitive to antidepressant treatments. Nature 1977, 266, 730-732. [CrossRef]

110. Lumia, A.R.; Teicher, M.H.; Salchli, F.; Ayers, E.; Possidente, B. Olfactory Bulbectomy as a Model for Agitated Hyposerotonergic Depression. Brain Res. 1992, 587, 181-185. [CrossRef]

111. O'Neil, M.F.; Moore, N.A. Animal models of depression: Are there any? Hum. Psychopharmacol. Clin. Exp. 2003, 18, 239-254. [CrossRef]

112. Barr, A.M.; Markou, A. Psychostimulant withdrawal as an inducing condition in animal models of depression. Neurosci. Biobehav. Rev. 2005, 29, 675-706. [CrossRef] [PubMed]

113. Bucan, M.; Abel, T. The mouse: Genetics meets behaviour. Nat. Rev. Genet. 2002, 3, 114-123. [CrossRef]

114. Scott, P.A.; Cierpial, M.A.; Kilts, C.D.; Weiss, J.M. Susceptibility and resistance of rats to stress-induced decreases in swim-test activity: A selective breeding study. Brain Res. 1996, 725, 217-230. [CrossRef]

115. Dulawa, S.C.; Hen, R. Recent advances in animal models of chronic antidepressant effects: The novelty-induced hypophagia test. Neurosci. Biobehav. Rev. 2005, 29, 771-783. [CrossRef]

116. Blanchard, R.J.; Hebert, M.; Sakai, R.R.; McKittrick, C.; Henrie, A.; Yudko, E.; McEwen, B.S.; Blanchard, D.C. Chronic social stress: Changes in behavioral and physiological indices of emotion. Aggress. Behav. J. Int. Soc. Res. Aggress. 1998, 24, 307-321. [CrossRef]

117. Katz, R.J.; Roth, K.A.; Carroll, B.J. Acute and chronic stress effects on open field activity in the rat: Implications for a model of depression. Neurosci. Biobehav. Rev. 1981, 5, 247-251. [CrossRef]

118. Willner, P.; Towell, A.; Sampson, D.; Sophokleous, S.; Muscat, R. Reduction of sucrose preference by chronic unpredictable mild stress, and its restoration by a tricyclic antidepressant. Psychopharmacology 1987, 93, 358-364. [CrossRef]

119. Qiao, H.; Li, M.-X.; Xu, C.; Chen, H.-B.; An, S.-C.; Ma, X.-M. Dendritic spines in depression: What we learned from animal models. Neural. Plast. 2016, 2016. [CrossRef]

120. Pereira, A.; Carvalho, M.; Padovan, C. Both serotonergic and noradrenergic systems modulate the development of tolerance to chronic stress in rats with lesions of the serotonergic neurons of the median raphe nucleus. Behav. Brain Res. 2019, $357,39-47$. [CrossRef] [PubMed]

121. Schoenfeld, T.J.; McCausland, H.C.; Morris, H.D.; Padmanaban, V.; Cameron, H.A. Stress and loss of adult neurogenesis differentially reduce hippocampal volume. Biol. Psychiatry 2017, 82, 914-923. [CrossRef]

122. Marsden, W. Synaptic plasticity in depression: Molecular, cellular and functional correlates. Prog. Neuro-Psychopharmacol. Biol. Psychiatry 2013, 43, 168-184. [CrossRef]

123. Ménard, C.; Pfau, M.L.; Hodes, G.E.; Russo, S.J. Immune and neuroendocrine mechanisms of stress vulnerability and resilience. Neuropsychopharmacology 2017, 42, 62-80. [CrossRef] [PubMed]

124. Yirmiya, R.; Goshen, I. Immune modulation of learning, memory, neural plasticity and neurogenesis. Brain Behav. Immun. 2011, 25, 181-213. [CrossRef] [PubMed]

125. Wang, Q.; Timberlake, M.A., II; Prall, K.; Dwivedi, Y. The recent progress in animal models of depression. Prog. NeuroPsychopharmacol. Biol. Psychiatry 2017, 77, 99-109. [CrossRef]

126. Can, A.; Dao, D.T.; Arad, M.; Terrillion, C.E.; Piantadosi, S.C.; Gould, T.D. The mouse forced swim test. J. Vis. Exp. 2012, e3638. [CrossRef]

127. Yoshino, S.; Hara, A.; Sakakibara, H.; Kawabata, K.; Tokumura, A.; Ishisaka, A.; Kawai, Y.; Terao, J. Effect of quercetin and glucuronide metabolites on the monoamine oxidase-A reaction in mouse brain mitochondria. Nutrition 2011, 27, 847-852. [CrossRef]

128. Kumar, A.; Garg, R.; Prakash, A.K. Effect of St. John's Wort (Hypericum perforatum) treatment on restraint stress-induced behavioral and biochemical alteration in mice. BMC Complementary Altern. Med. 2010, 10, 1-6. [CrossRef]

129. Liaquat, L.; Batool, Z.; Sadir, S.; Rafiq, S.; Shahzad, S.; Perveen, T.; Haider, S. Naringenin-induced enhanced antioxidant defence system meliorates cholinergic neurotransmission and consolidates memory in male rats. Life Sci. 2018, 194, 213-223. [CrossRef] 
130. Jeon, S.W.; Kim, Y.K. Inflammation-induced depression: Its pathophysiology and therapeutic implications. J. Neuroimmunol. 2017, 313, 92-98. [CrossRef] [PubMed]

131. Wium-Andersen, M.K.; Orsted, D.D.; Nielsen, S.F.; Nordestgaard, B.G. Elevated C-reactive protein levels, psychological distress, and depression in 73,131 individuals. JAMA Psychiatry 2013, 70, 176-184. [CrossRef]

132. Khandaker, G.M.; Pearson, R.M.; Zammit, S.; Lewis, G.; Jones, P.B. Association of serum interleukin 6 and C-reactive protein in childhood with depression and psychosis in young adult life: A population-based longitudinal study. JAMA Psychiatry 2014, 71, 1121-1128. [CrossRef] [PubMed]

133. Erickson, K.I.; Miller, D.L.; Roecklein, K.A. The Aging Hippocampus: Interactions between Exercise, Depression, and BDNF. Neuroscientist 2012, 18, 82-97. [CrossRef]

134. Halder, S.; Kar, R.; Mehta, A.K.; Bhattacharya, S.K.; Mediratta, P.K.; Banerjee, B.D. Quercetin Modulates the Effects of Chromium Exposure on Learning, Memory and Antioxidant Enzyme Activity in F1 Generation Mice. Biol. Trace Elem. Res. 2016, 171, 391-398. [CrossRef] 